\title{
Working
}

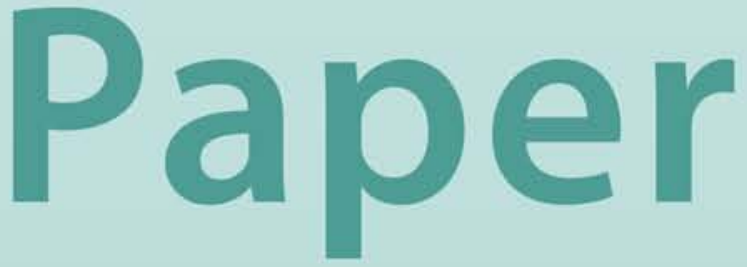




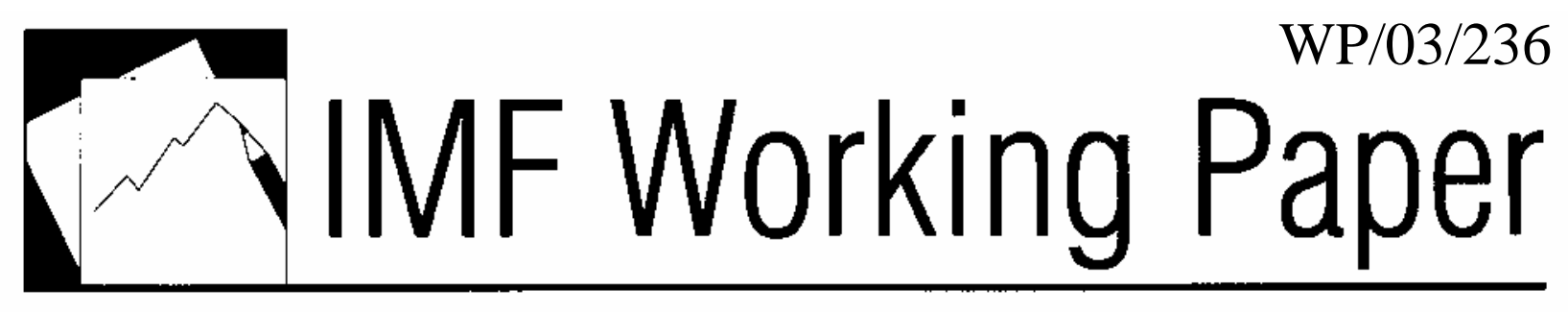

\section{Cross-Border Listings, Capital Controls, and Equity Flows to Emerging Markets}

Hali Edison and Francis E. Warnock 


\title{
IMF Working Paper
}

\author{
Research Department
}

\section{Cross-Border Listings, Capital Controls, and Equity Flows to Emerging Markets}

\author{
Prepared by Hali Edison and Francis E. Warnock ${ }^{1}$ \\ Authorized for distribution by Jonathan D. Ostry
}

December 2003

\begin{abstract}
This Working Paper should not be reported as representing views of the IMF. The views expressed in this Working Paper are those of the author(s) and do not necessarily represent those of the IMF or IMF policy. Working Papers describe research in progress by the author(s) and are published to elicit comments and to further debate.
\end{abstract}

We analyze capital flows to emerging markets in a framework that incorporates two quantitative measures of financial integration, the intensity of capital controls and the extent of cross-border listings, while controlling for traditional global (push) and country-specific (pull) factors. Two important results emerge. First, the cross-listing of an emerging market firm on a U.S. exchange is an important but short-lived capital flows event, suggesting that the cross-listed stock is in effect a new security that U.S. investors quickly bring into their portfolios. Second, the effect of financial liberalization on capital flows is more nuanced than is suggested by event studies: A reduction in capital controls results in increased inflows only when the controls are binding. Among the standard push and pull factors, global factors are important—slack U.S. economic activity is associated with increased flows to emerging markets—and U.S. investors appear to chase expected, but not past, returns.

\section{JEL Classification Numbers: G11, G15, F3}

Keywords: portfolio equity flows, capital flows, emerging markets, and ADRs

\section{Authors’ E-Mail Addresses: hedison@imf.org, frank.warnock@frb.gov}

\footnotetext{
1 The authors are, respectively, Senior Economist in the IMF's Research Department and Economist in the Division of International Finance at the Federal Reserve Board. The authors thank, for helpful comments and suggestions, Campbell Harvey, Jean Imbs, Assaf Razin, Leigh Riddick, Jonathan Wright, and participants at the CEPR/London Business School Conference on International Capital Flows, the Kellogg School of Management Conference on Investments in Imperfect Capital Markets, the International Finance Division's Monday Workshop, and at seminars at the Federal Reserve Bank of New York, University of Sydney, Washington Area Finance Association, Western Economic Association, and World Bank. We also thank Jean Tobin at the NYSE for data on listings of foreign stocks; Alka Banerjee of Standard and Poor's for helping us with the S\&P/IFC data; and Nancy Baer, Sara Holland, and Ben Sutton for research assistance. The views in this paper are solely the responsibility of the authors and should not be interpreted as reflecting the views of the Board of Governors of the Federal Reserve System or the International Monetary Fund, or of any other person associated with the Federal Reserve System or the IMF.
} 


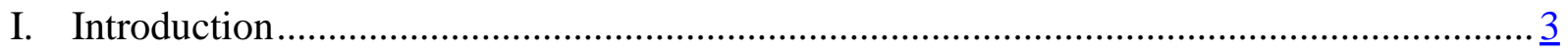

II. The Modeling Framework and Data .........................................................................

A. Bilateral Equity Flows_-A Short Primer ...............................................................

B. International Financial Integration.........................................................................

C. Proxies for Expected Risk and Return: The Standard Push and Pull Factors.................10

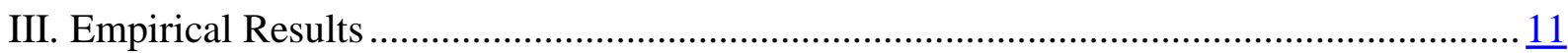

A. Results from Long-Horizon Regressions ........................................................

B. Results from Short-Horizon Regressions............................................................ $\frac{13}{14}$

C. Robustness Check—Rolling Regressions .............................................................

D. Summary of Results and Comparison with Past Results ............................................. 15

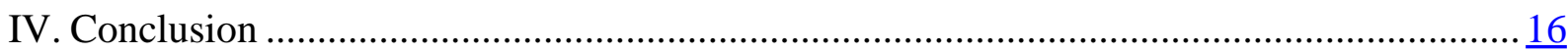

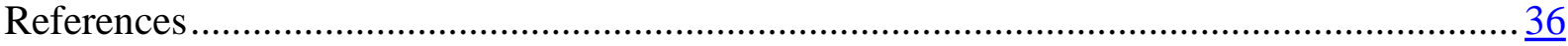

Appendices

A. Description of Data and Sources.................................................................................

B. Listings on U.S. Stock Exchanges ..........................................................................

Tables

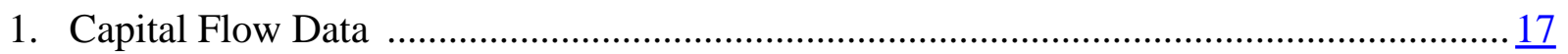

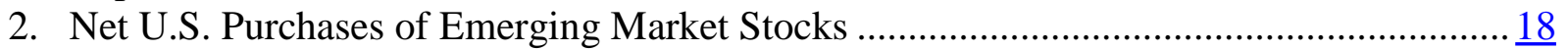

3. Summary Statistics for Latin American Panel............................................................

4a. Panel Data Estimates of 12-Month Ahead Equity Flows ……………………………... 20

4b. Panel Data Estimates of 12-Month Ahead Equity Flows (with first differences) ............... 21

5. Estimation Results, 12-Month Ahead Equity Flows...................................................22

6. Panel Data Estimates of One-Month Ahead Equity Flows............................................... 23

7. Estimation Results, One-Month Ahead Equity Flows ...................................................24

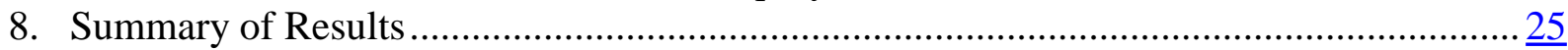

Figures

1. Monthly Net Purchases of Equities by U.S. Investors .................................................26

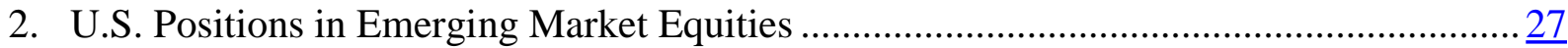

3. Restrictions on Foreign Ownership of Equities ......................................................

4. New Listings of Emerging Market Stocks on U.S. Exchanges ........................................

5. Standard Country-Specific (or "Pull") Factors ………………………………………........ $\frac{30}{31}$

6. Global (or "Push") Factors............................................................................................

7. Fit of Long-Horizon Regressions, 1989-99................................................................. $\frac{32}{33}$

8. Coefficient Estimates from Rolling Regressions-Mexico.............................................. $\frac{33}{34}$

9. Coefficient Estimates from Rolling Regressions-Korea ................................................

10. Korea—Capital Controls and Equity Flows …………………………............................ 


\section{INTRODUCTION}

International capital flows have skyrocketed over the past decade. Net private capital flows to emerging market countries tripled from $\$ 50$ billion a year during 1987-89 to more than $\$ 150$ billion a year over 1995-97. These flows, however, receded somewhat with the 1997-99 financial crises that spread from Asia to Russia and on to Latin America. During much of this period, policymakers in emerging markets were confronted with the challenges posed by capital inflows and, more recently, concern about the impact of dramatic reversals. Although countries have shared increases in capital flows, there has also been considerable variation among countries in the timing, duration, and magnitude of these flows and their reversals.

Table 1 presents data on private capital flows to Latin America and Asia. Portfolio equity flows are usually smaller than direct investment or bond flows, but their share can be quite volatile. In both Latin America and emerging Asia, the share of equity inflows increased in the early 1990s and peaked in 1993. By 1998, equity flows had all but dried up in Latin America, but were somewhat more resilient in Asia; in 1999 equities represented 34 percent of net inflows into Asia.

The goal of this paper is to explain the factors motivating the relatively volatile portfolio equity flows that appear in Table 1 . To do so we synthesize two strands of the international finance literature: (i) analysis of international financial integration represented by two factors, the degree of international financial liberalization and the wave of cross-border equity listings, and (ii) push-pull analysis of capital flows that investigates the roles of global factors beyond the control of emerging market economies (push factors) and local economic conditions and policies (pull factors).

We extend the capital flows literature by analyzing the role of two integration variables: an explicit quantitative measure of the intensity of capital controls and a measure of the extent of cross-border listings. Capital controls are explicitly addressed in the capital flows studies of Montiel and Reinhart (1999), who analyze annual flows and model capital controls as a $(0,1,2)$ variable, and Bekaert, Harvey, and Lumsdaine (2002), who model capital controls as a $(0,1)$ dummy variable based on the date of the initial opening of a market to foreign investment. We use the Edison and Warnock (2003a) capital controls measure, which captures not only the date of the initial opening of a market, but also the extent of that opening and the evolution and intensity of subsequent changes in controls. Based on this measure, our results suggest that the relaxation of binding capital controls leads to increased inflows, consistent with the event study findings of Bekaert, Harvey, and Lumsdaine (2002) and Edison and Warnock (2003a). Our results do not, however, imply that every loosening of capital controls will spark inflows; for example, the easing of nonbinding capital controls by some East Asian countries during the financial crisis of 1997 did not immediately result in increased inflows.

Our second integration variable measures the extent of cross-border listings, or securities migration, from developing to industrial country markets. The analysis of cross-border listings is important because it is an open question whether access to global investors is 
generally available to emerging markets or limited to those firms that go through the process of listing on developed country exchanges. ${ }^{2}$ While we cannot directly answer this question with our dataset-firm-level capital flows data are required-we can address it indirectly by analyzing the effect of cross-border listings on capital flows. We find that international financing does appear to be limited in time and scope to the cross-listing event. The cross-listing results in an immediate surge in capital inflows, but with little if any follow-through, suggesting that an equity newly listed on a U.S. exchange is in effect a new security that is quickly incorporated into U.S. portfolios. All of these stocks were available to U.S. investors prior to the cross-listing, so it is natural to ask why they should be treated as new securities. A plausible answer is that the information content inherent in U.S. investor protection regulations (or IPRs) — which includes reconciliation to U.S. Generally Accepted Accounting Principles and adherence to the U.S. Security and Exchange Commission's disclosure requirements and securities laws_-transforms the existing security. ${ }^{3}$

While our analysis of the effects of capital controls and cross-border listings provides novel results, in line with previous research we find important roles for global "push" factors, such as U.S. economic activity and U.S. interest rates. ${ }^{4} \mathrm{We}$ also find evidence that investors are chasing prospective returns, as proxied by dividend yields, but not past returns. ${ }^{5}$ Thus, our empirical results tell the following story: Emerging markets experience increased inflows when U.S. economic activity is weak (and hence profit prospects for U.S. firms are weak), U.S. interest rates are low (causing investors to seek higher returns, but also reducing emerging market borrowing costs), binding capital controls are relaxed, prospective returns increase, and, most importantly, when individual equities are cross-listed.

The paper is organized as follows. The next section highlights the modeling framework we employ, discusses the role of cross-border equity listings in equity flows, and describes our capital controls variable and the data used in the empirical analysis. Section 3 presents our

\footnotetext{
${ }^{2}$ For papers on securities migration, see Claessens, Klingebiel, and Schmukler (2002), Karolyi (2003), and Pulatkonak and Sofianos (1999).

${ }^{3}$ The view that an equity newly listed on a U.S. exchange is in effect a new security is consistent with the evidence of divergent behavior of owners of Mexican local and cross-listed firms (Tribukait, 2003) and abnormal returns in the run-up to the listing (Foerster and Karolyi, 1999).

${ }^{4}$ Chuhan, Claessens, and Mamingi (1998) found that push factors-the decrease in U.S. interest rates and the slowdown in U.S. industrial production-help explain flows to both Latin American and emerging Asian countries from 1988 to 1992, and that pull factors such as equity returns or credit ratings matter for flows to Asia but not necessarily for Latin American flows. Calvo, Leiderman, and Reinhart (1993) also find evidence of an important role for global factors.

${ }^{5}$ The evidence on past-returns-chasing behavior is mixed. Using monthly data, Bohn and Tesar (1996) find that investors chase past returns in 7 of 22 markets. The literature that focuses on information asymmetries using high frequency flows provides conflicting evidence; see, for example, Dvorak (2002), Choe, Kho, and Stulz (2001), and Seasholes (2000).
} 
single-country and panel regression results along with robustness checks. Section 4 contains concluding remarks.

\section{The Modeling FrameWORK AND DATA}

We augment a standard asset pricing/capital flows model with integration variables that capture the intensity of both capital controls and cross-border listings. In a standard framework of capital flows in a capital asset pricing setting, as in Bohn and Tesar (1996) and Chuhan et al. (1998), the desired portfolio weights at time $\mathrm{t}$ for assets in $\mathrm{N}$ countries is

$$
p_{t}=\gamma^{-1} \Omega_{t}^{-1} v_{t}+\eta_{t}
$$

where $p$ is an Nx1 vector of portfolio shares, $\gamma$ is a risk aversion parameter, $v$ is an Nx1 vector of expected excess returns, $\Omega$ is the NxN covariance matrix of expected returns, and $\eta$ is the component of portfolio unrelated to returns. With time-varying expected returns and heterogenous investors, the portfolio weights in (1) will change and net equity flows will occur.

In the remainder of this section, we describe the flows data and our explanatory variables in greater detail.

\section{A. Bilateral Equity Flows-A Short Primer}

The capital flows data we analyze are monthly portfolio equity flows from the United States to emerging market countries, compiled by the U.S. Treasury International Capital (TIC) Reporting System. ${ }^{6}$ U.S. net purchases of securities in a given country are defined as gross purchases of foreign securities by U.S. residents from residents of that country minus gross sales of foreign securities from U.S. residents to residents of that country.

Figure 1 gives a sense of the nature of the monthly capital flow data and illustrates three facts. First, U.S. investors "discovered" Latin American equity markets in the early 1990s, but did not begin to invest in Asian emerging markets until a few years later. Second, the

\footnotetext{
${ }^{6}$ Griever, Lee, and Warnock (2001) is a primer on the TIC data, which have been used in Tesar and Werner (1994), Brennan and Cao (1997), Taylor and Sarno (1997), Chuhan et al. (1998), and Bekaert et al. (2002). Other sources on capital flows data exist. Global (not bilateral) flows are available from the IMF'S International Financial Statistics database, but not for all countries and typically only annually or at best quarterly. High frequency capital flows data are available from proprietary sources, although it is difficult to gauge the scope of their coverage. Froot, O'Connell, Seasholes (2001) use proprietary data that include only transactions by State Street clients for which the countries of the currency and the foreign equity are the same. This excludes trading in ADRs, which are likely a large and variable portion of cross-border trading (Pulatkonak and Sofianos, 1999; Ahearne, Griever, and Warnock, forthcoming). Our data include transactions in ADRs. High frequency flows over short periods have also been analyzed by Richards (2002) and Griffin, Nadari, and Stulz (2002).
} 
effects of two crises are evident. The Mexican crisis of 1994 coincided with a prolonged period of relatively small inflows to Latin America, but only a brief pause in flows to Asia. In contrast, the effects of the Asian financial crisis of 1997/1998 appear to be greater in Latin American countries, which saw U.S. investors sell their equities on net, than in Asia, where equity purchases by U.S. investors only slowed. Finally, the figures highlight a feature of the flow data that any modeling approach must address, the lumpiness in equity purchases that appears as large spikes in the data. We aim to model the spikes, but also smooth the data by estimating long-horizon regressions.

There are three aspects of the monthly TIC data that can confound the analysis of capital flows: coverage is limited to flows that involve U.S. residents, trades through third countries result in a geographical bias in bilateral flows data, and equity financing of cross-border mergers makes it increasingly difficult to analyze equity flows. In the remainder of this section, we consider the effects of these three issues on our sample.

\section{Coverage Is Limited to U.S. Investors}

The TIC data are bilateral portfolio flows into and out of the United States and, hence, do not include other countries' investments in emerging markets. The ideal data for a study of capital flows is a world matrix of flows at the highest frequency possible, with the $i, j$ element giving the net flow from country $i$ into country $j$ 's securities. Unfortunately, such a data set does not exist, as very few countries collect bilateral capital flows data. As Table 2 implies, equity flows from other countries are also important - the share of U.S. to global flows to these regions ranges from 15 to 50 percent-but since so few countries collect bilateral capital flows data, we cannot expect much better coverage than the TIC data.

\section{Trades Through Third Countries}

A strong but common assumption - that the countries of the foreign intermediary and foreign issuer are identical - must be made when using transactions-based capital flows data. It is by now well understood that capital flows data collected for balance of payments purposes are based on the country of the foreign intermediary, which is not necessarily the country in which the issuer of the foreign security resides. The common assumption that the countries of the intermediary and issuer are the same is clearly is not true for trades through financial centers, which skew the geography of capital flows (Warnock and Cleaver, 2003).

To determine whether the TIC data for the countries in our sample are accurate, following Warnock and Cleaver (2003) we use the flows data to estimate positions and compare the estimated position to a measured amount from a benchmark survey (Figure 2). While there are many other variables that go into the calculation of the estimates-for example, valuation adjustments-egregious discrepancies between the estimate and the survey amount suggest problems with the country attribution of the capital flows data. As can be seen in the figure, with the possible exception of Brazil, the TIC flows data appear to be rather accurate for these countries, especially given the large valuation changes associated with the Asian crisis.

\section{Merger-Related Stock Swaps}

Cross-border mergers and acquisitions have increasingly been financed by "stock swaps" whereby shareholders of the target company receive shares in the new (or existing) foreign 
company. For example, when Daimler acquired Chrysler, shares of Chrysler were "swapped" for Daimler Chrysler shares. Such acquisitions are not included in the TIC data, but any "flowback" is. ${ }^{7}$ This has a greater impact on studies of industrial country capital flows, such as flows opposite Germany or the United Kingdom, because of the large Daimler Chrysler and BP Amoco mergers. The bottom line of Table 2 shows, however, that stock swaps do not affect our emerging markets sample.

\section{B. International Financial Integration}

In this subsection we discuss two new variables that we use to capture financial integration, a capital controls variable and a measure of cross-listings.

\section{Capital Controls}

Many countries opened their financial markets to foreign investment to various degrees during our sample period. In the model of Bacchetta and van Wincoop (2000), integration with world financial markets results in a sharp increase in capital inflows (as global investors include the country's equities in their portfolios) that eventually levels out after portfolios have been rebalanced. The first part of this process - the post-liberalization increase in inflows - has been documented in Bekaert et al. (2002) and Edison and Warnock (2003a).

That countries experience inflows when they open their financial markets should not come as a surprise. The liberalization process, however, is not a one-time event that is uniform across countries. Financial liberalizations vary greatly in their extent (full or incomplete) and evolution (one-time event or gradual). ${ }^{8}$ To capture this we use the monthly the monthly measure of the intensity of capital controls developed in Edison and Warnock (2003a). ${ }^{9}$ The measure uses the fact that the International Finance Corporation's Global Index (IFCG) is designed to capture the entire market and an individual stock's weight in the Investable Index

\footnotetext{
${ }^{7}$ Consider, for example, three strategies that were available to Chrysler shareholders who were content with the share of foreign equities in their portfolios prior to the swap. They could have sold Chrysler after the merger was announced but before it occurred, which would have no confounding effect on capital flows data. If they decided that Daimler Chrysler was a better way to get exposure to Germany than other German equities, they might have rebalanced their portfolios by selling other German stocks before or after the swap. Such sales would appear in the TIC data, so the swap should be added to the flows data as a purchase. Finally, they could have sold Daimler Chrysler after the swap, which would also appear as sales in the TIC data; again, the swap should be entered as a purchase.

${ }^{8}$ In this paper, as is customary in the international finance literature, we typically use the term financial liberalization when international financial liberalization (i.e., the opening of capital markets to foreigners or a reduction in capital controls) would be more appropriate. For a discussion of the link between domestic and international financial liberalization, see Levine (2001).

${ }^{9}$ Other measures of capital controls exist, but are annual or do not capture the intensity of controls. See, for example, Alesina, Grilli and Milesi-Ferretti (1994), Quinn (1997), Rodrik (1998), Montiel and Reinhart (1999), and the survey by Eichengreen (2001).
} 
(IFCI) is determined mainly by legal restrictions. Thus, the ratio of the market capitalizations behind the IFCI and IFCG is an indication of a country's openness, and the following formula provides a measure of the intensity of foreign ownership restrictions:

$$
F O R_{i, t}=1-\frac{M C_{i, t}^{I F C I} / p_{i, t}^{I F C I}}{M C_{i, t}^{I F C G} / p_{i, t}^{I F C G}}
$$

where $P$ denotes the price indices and $M C$ denotes the market capitalization of the index. Deflating by the price indices eliminates relative market capitalization changes that might arise from asymmetric shocks to investable and global stocks. ${ }^{10}$ The measure is narrow in that it focuses on just one component of capital controls, although an appropriate one for modeling equity flows.

Figure 3 shows the measure of foreign ownership restrictions from 1989 through 2000 for the nine countries in our sample. FOR can vary from zero to one, with zero representing a completely open market with no restrictions, and a value of one indicating that the market is completely closed. The figures underscore regional differences in initial liberalizations and the evolution of the liberalization process. Latin American economies liberalized much earlier and more completely than emerging Asia, where the liberalization process was more gradual. This echos the intuition in Bacchetta and van Wincoop (2000) and Bekaert and Harvey (1995) and begs the following question: What is the effect on inflows of a marginal liberalization?

In theory the likely effect of changes in capital controls on U.S. equity investment in emerging markets is straightforward-a loosening of controls should expand the investment opportunity set and result in increased purchases. In practice, the effect is ambiguous. For example, if binding foreign ownership restrictions (such as when a market is completely closed) are relaxed, we would expect increased net purchases. However, if foreign ownership restrictions are non-binding — such as during a financial crisis when capital flows dry up-a relaxation might not result in increased inflows.

\section{Cross-Border Listings}

A further complicating factor in analyzing capital flows to emerging markets is the wave of cross-border listings of equities, which began in earnest in the 1990s. On U.S. exchanges, the stock can be directly listed, but the usual vehicle is a listing through a Level II or Level III ADR. The potential advantages of listing on a U.S. exchange include an enlarged investor base, increased visibility, a highly liquid secondary market, and the opportunity to raise new capital. ${ }^{11}$ From the investor's perspective, the cross-listing mitigates some of the

\footnotetext{
${ }^{10}$ If, for example, bank stocks are not available to foreigners, a pure banking sector shock would change the relative price of investable stocks and, hence, change relative market capitalizations.

${ }^{11}$ Studies of cross-listing behavior include Karolyi (1998), Pagano, Roell, and Zechner (2002), Lins, Strickland, and Zenner (2000), and Claessens, Klingebiel, and Schmukler (2002).
} 
uncertainties and costs involved with making direct purchases in foreign markets. Investing directly in a foreign market involves not only higher transaction costs and a greater likelihood of failed trades, but also potentially poor financial information that owes to varied accounting practices, disclosure requirements, and enforcement. All of these costs-direct and informational - are likely alleviated when a foreign firm lists on a U.S. exchange. Indeed, compared to firms that are only available on home exchanges, cross-listed firms have higher valuations (Doidge, Karolyi, and Stulz, forthcoming); more accurate analyst forecasts (Lang, Lins, and Miller, forthcoming); and less evidence of insider trading (Tribukait, 2003). Moreover, Edison and Warnock (2003b) show that U.S. investors are more likely to hold a foreign stock that is listed on a U.S. exchange.

The improvement in the quality of financial information associated with the listing leads us to think of a cross-border listing as a new security, whether or not it is an IPO. Standard portfolio theory suggests that when a new security becomes available, investors will immediately include it in their portfolios at the desired weight. The likely effect on equity flows data is clear: At the time of the listing, equity flows should exhibit a sharp increase. ${ }^{12}$ An interesting empirical question is whether the increase persists or is temporary. That is, is the international financing associated with a cross-listing ongoing or a one-time event?

Our cross-border listing variable, $C B L$, includes equities that are listed on U.S. exchanges either directly or as exchange-traded (or Levels II and III) ADRs, because these are the only foreign securities that are subject to the SEC's stringent disclosure and reconciliation requirements. ${ }^{13} \mathrm{CBL}$ is the share of a country's stock market that is newly listed on a U.S. exchange in a given month. For example, BAESA was $2.3 \%$ of the Argentinian market when it listed on the NYSE in May 1993; in that month, $C B L$ is 0.023 for Argentina. Figures 4a and $4 \mathrm{~b}$ illustrate the timing of U.S. listings; the size and dates of cross-listings are presented in Appendix B. ${ }^{14}$ Latin American cross-listings came in waves; they began in the early 1990s, surged in 1993 and 1994, slowed with the Peso crisis of December 1994, and picked up by 1997 only to slow again with the Asian financial crisis. In contrast, Asian cross-listings were much more muted, occurring primarily in the mid-1990s, when large public utilities from Korea, Indonesia, and the Philippines listed on the NYSE. Moreover, no firms from Malaysia or Thailand listed on a U.S. exchange in our entire sample period. Finally, the

${ }^{12}$ In U.S. capital flows data, ADRs are treated just as any other foreign stock. Transactions between a U.S. resident and a foreign resident are recorded, while those between two foreign or two domestic parties are not.

${ }^{13}$ Foreign securities that trade only as private placements (through rule 144A) or over the counter (Level I and unsponsored) may have reduced transaction costs compared to securities that trade only in emerging markets, because the need to hire a global custodian in the local market is circumvented and liquidity may be better in New York.

${ }^{14}$ Because international securities transactions are reported to the TIC system using settlement date accounting, we move to the following month any listing that occurs in the last three business days of a month (last five days of the month for listings prior to June 1995). 
effect of the Asian financial crisis is clear in Figure 4b; no firm from emerging Asia listed on a U.S. exchange between the fall of 1997 and mid-1999, and then only Korean ones. ${ }^{15}$

\section{Proxies for Expected Risk and Return: The Standard Push and Pull Factors}

Net equity inflows into emerging markets should be related to changes in expected risk and return. No direct measures of expected risk and return are available, so we follow the literature and rely on proxies-the so-called global "push" and country-specific "pull" factors.

We include two country-specific factors that capture past and prospective returns. As in Bekaert et al. (2002), we include lagged excess returns (excess of the foreign market over the U.S. market) to capture returns-chasing or positive feedback trading. For expected returns, we use the dividend-price ratio, or dividend yield, which has been shown to have forecasting power for returns (Fama and French, 1988; Campbell and Shiller, 1988; Harvey, 1995). If U.S. investors chase past (prospective) returns, an increase in past returns (dividend yields) should be associated with increased capital inflows. Regional aggregates illustrate that returns and dividend yields have been much more volatile in Latin America than in emerging Asia (Figure 5).

For a risk measure we use the log of the International Country Risk Guide's (ICRG) Composite Index, which Erb, Harvey, and Viskanta (1996) show to have predicted power for expected returns. ${ }^{16}$ The ICRG rating is such that a higher number indicates less risk, so we expect higher ICRG risk ratings (that is, lower risk) to be associated with higher equity inflows.

The global factors that we consider are U.S. interest rates and the deviation from trend growth in U.S. industrial production. As U.S. interest rates increase, so does U.S. investors' risk-free rate of return; for constant relative returns, foreign investment becomes less attractive and lower cross-border net purchases are likely. An increase in U.S. interest rates also increases borrowing costs for emerging markets, thereby reducing expected profits. Stronger economic activity in the U.S. points toward higher future profits for U.S. firms and, hence, less equity investment abroad; counteracting this, however, may be a wealth effect that prompts U.S. investors to invest more.

The work of Calvo et al. (1993) told us that low interest rates and slack economic activity in the United States coincides with greater capital flows to emerging markets. Our somewhat

${ }^{15}$ Figure $4 \mathrm{a}$ and $4 \mathrm{~b}$ do not give an indication of the portion of each country's market listed on U.S. exchanges at a point in time. By the end of 1999, stocks representing about half of the Mexican, Argentinian, Chilean, Korean and Philippine markets, and about one quarter of the Brazilian and Indonesian markets, were cross-listed on the NYSE and NASDAQ.

${ }^{16}$ Credit spreads on secondary market debt prices are another indicator of investment prospects, but are not available for a wide range of countries and, where available, start only in the early 1990s. 
longer sample, however, suggests that this result should be revisited. To be sure, a comparison of Figures 6 and 1 shows that the initial surge in equity flows to Latin America coincided with falling U.S. interest rates and below-trend U.S. economic activity. Faced with these conditions, U.S. investors ventured abroad and Latin America, particularly Mexico, saw inflows increase substantially. And increasing U.S. interest rates in 1994 coincided with a substantial slowdown in flows to Latin America, as predicted by the evidence in Calvo et al. (1993). However, at the same time flows to Asia were quite strong and flows did not increase to either region in late 1998 when U.S. rates decreased sharply, suggesting that a re-examination of the role of push factors is warranted.

\section{EMPIRICAL RESUlTS}

We estimate regional (fixed effects) panel regressions and, to determine the extent that factors significant for flows to the regions are also important for individual countries, single-equation country-level regressions. In our regressions, all explanatory variables are dated at month $t$, except $C B L_{t+1}$. The dependent variable is (average) monthly equity inflows from month $t+1$ to month $t+k$ scaled by local market capitalization, where $k=12$ (long-horizon 12-month ahead flows) or $k=1$ (short-horizon one-month ahead flows). In particular, we estimate equations for $Y_{i}$, net U.S. purchases of stocks in country $i$ scaled by country $i$ 's market capitalization, of the following form:

$$
\begin{aligned}
& \frac{\sum_{j=1}^{k} Y_{i, t+j}}{k}=\alpha+\beta_{i 0} \operatorname{RISK}_{i, t}+\beta_{i 1} R E T_{i, t}+\beta_{i 2} D Y_{i, t}+\beta_{i 3} C B L_{i, t+1}+\beta_{i 4} F O R_{i, t} \\
& +\beta_{i 5} U_{S I P_{T}}+\beta_{i 6} \operatorname{USBOND}_{t}+\eta_{t+k}
\end{aligned}
$$

where the country-specific variables for country $i$ are

$R_{L} \quad$ period $t$ ICRG Composite Risk Index (logged)

$R E T_{t} \quad$ period $t$ returns relative to returns on $\mathrm{S} \& \mathrm{P} 500$

$D Y_{t} \quad$ period $t$ dividend yield

$C B L_{t+1} \quad$ new exchange-traded cross-border listing in period $t+1$ (as a share of the foreign market capitalization)

$F_{t} \quad$ period $t$ foreign ownership restrictions

and for all countries the U.S. factors are

USIP $\quad$ period $t$ deviation of U.S. industrial production from a linear trend $U S B O N D_{t} \quad$ period $t$ interest rate on a 10-year U.S. Treasury bond

Based on the discussion in the previous section, we expect the coefficients on RET, DY, RISK, and CBL to be positive; USIP and USBOND to be negative; and FOR to be positive or negative depending on the environment in which capital controls were adjusted. Summary statistics for our dependent variables are presented in Table 3. 
We estimate long-horizon regressions for two reasons. First, long-horizon regressions alleviate endogeneity issues. Whereas past or current equity flows may well influence governments' decisions to adjust capital controls or firms' decisions to cross-list on foreign stock exchanges, it is less likely that the decisions to cross-list or adjust capital controls today are influenced by flows over the subsequent twelve months. Second, long horizons effectively smooth the very volatile data on net purchases without aggregating and discarding information. ${ }^{17}$

\section{A. Results from Long-Horizon Regressions}

The effects of U.S. factors, standard local factors, the intensity of capital controls, and cross-border listings on 12-month ahead equity flows are shown in the regional panel results reported in Table 4a. The table shows results over the January 1989 to December 1999 period for Latin America and emerging Asia, as well as a slightly shorter emerging Asia sample that also includes Indonesia.

In both Latin America and emerging Asia, U.S. factors matter. Higher U.S. interest rateswhich can lead to higher borrowing costs and reduced output in emerging markets-lead to reduced flows, but only significantly so in the Asia ex Indonesia sample. In every sample, above trend U.S. economic activity - which could signal greater prospective profits and, hence, higher expected returns for U.S. companies - results in significantly lower equity flows to EMEs over the next year. For example, with U.S. industrial production running about 10 percent below trend in the early 1990s, long-horizon flows to Latin America and emerging Asia increased about 0.1 and 0.02 percent of market capitalization per month. Over a twelve-month period, these flows amount to 1.2 and 0.24 percent of market capitalization, respectively, economically significant amounts.

There is no evidence in Table 4a that U.S. investors chase past returns-RET is insignificant in every regression - but evidence of prospective returns chasing is apparent, as higher dividend yields result in greater inflows over the next year, significantly so in one sample (Asia ex Indonesia). The level of risk, as measured by the ICRG Composite Index (for which a higher number corresponds with less risk), in not significant in any of our samples.

The impact of the integration variables varies across regions. A reduction in capital controls results in a significant increase in long-horizon equity flows to emerging Asia, but not to Latin America. A cross-border listing has a positive long-horizon effect on equity flows to Latin America but not emerging Asia. It should be noted that the sample of cross-listed emerging Asian firms is quite limited; compared to 72 Latin American cross-listings, only

\footnotetext{
${ }^{17}$ Long-horizon regressions are often used when modeling stocks returns; see the discussion in Campbell, Lo and MacKinlay (1997). Note that the long-horizon regressions impose an overlapping structure on the data that induces correlation in the errors. To correct for this autocorrelation-which for 12-month ahead regressions cannot be of order greater than eleven-we use Newey and West (1987) standard errors that effectively widen traditional standard errors on persistent explanatory variables.
} 
15 Asian firms cross-listed on U.S. exchanges in our sample, five of which are from Indonesia (and therefore excluded from the ex. Indonesia sample).

As we have noted, the overlapping nature of long-horizon flows induces autocorrelation. While the Newey-West standard errors in our long-horizon regressions address this issue, a reasonable skeptic might note that two variables in particular-capital controls and risk ratings-have trended downward over the course of our sample and, hence, might produce spurious correlations. Table $4 \mathrm{~b}$ presents our long-horizon panel results with FOR and RISK entered as first differences rather than levels. The results are nearly identical to those in Table 4a.

Table 5 presents country-level regressions that may shed more light on the panel results. In general, the county-level results are consistent with the panel results but, not surprisingly, effects differ across countries. For example, a reduction in capital controls leads to increased long-horizon flows to five of the nine countries. In Korea, however, reduced capital controls are associated with lower long-horizon inflows; we address this case in greater detail below. The chasing of past returns is evident in only one country (Mexico), but prospective returns are important in five country-level regressions. U.S. factors-industrial production more so than bond rates-are important factors for flows to most countries. The long-term effect of a cross-listing is positive and significant in only two (Argentina and Chile) of the seven countries that have ADR programs. Figure 7 shows the fit of our long-horizon regressions; in most countries, our regressions adequately capture the main trends in 12-month ahead flows.

\section{B. Results from Short-Horizon Regressions}

Table 6 presents our panel results on the determinants of short-horizon equity flows. U.S. factors are again very important—-perhaps more so than in the long-horizon regressions-and there is some evidence of prospective returns chasing behavior. In contrast to the long-horizon results, higher past returns lead to short-horizon inflows, at least in Latin America. As with the long-horizon regressions, a reduction in capital controls results in inflows that are statistically significant in Asia. The coefficients on $C B L$ are large and highly significant in all but the Asia ex Indonesia sample (which, recall, has only 10 instances of a cross-border listing).

To compare the magnitudes of coefficient estimates in Tables 4a and 6, note that Table 4a is a regression of average monthly flows over the next year, while Table 6 models flows over the next month. In Table 4a, to calculate the effect on cumulated flows over an entire year, multiply the coefficient estimate by twelve. Thus, if the coefficients are the same across the tables, the effect over the year is twelve times that of the one-month effect and the effect has persistence. If the coefficient in Table $4 \mathrm{a}$ is one-twelfth of that in Table 6 , the one-month effect is equivalent to the cumulated effect over the entire year and the effect is transitory.

Comparing the coefficient estimates shows that they are similar across the two tables for many of the significant variables, suggesting that the short-horizon effects continue over an entire year. For example, the coefficients on U.S. IP in Tables $4 \mathrm{a}$ and 6 are identical, indicating that IP's one-period effect persists over the long horizon. For one variable, 
however, the contrast between the long- and short-horizon coefficients is striking. The coefficients for the cross-listing variable are much more significant but also much larger in the short-horizon regressions, suggesting that the portfolio rebalancing effect is very important but also short-lived. For example, a new ADR program by a firm that is ten percent of the home market raises equity inflows that month by 0.574 percent and 0.466 percent of market capitalization in Latin America and Asia, respectively. But the longer run effect is insignificant in Asia, and only .0875 percent per month, or 1 percent over twelve months, in Latin America. Thus, most if not all of the effect of a cross-listing occurs in the month of the listing. ${ }^{18}$ The significant but short-lived portfolio rebalancing effect is even more striking in the regressions for individual countries. Comparing Tables 5 and 7, short-horizon coefficients are about ten times greater than long-horizon coefficients, suggesting that most of the effect occurs in the month of the listing.

\section{Robustness Check-Rolling Regressions}

The short- and long-horizon regressions improve our understanding of equity flows to emerging markets, but we are concerned about parameter stability. Equity flows to emerging markets are a relatively new phenomenon that started in earnest only in the early 1990s and since have surged, plummeted, and, more recently, settled into a very low level. Not knowing what a "normal" period for emerging market flows looks like, we are not willing to claim that our parameter estimates are likely to remain constant.

To shed more light on the relationships between our explanatory variables and equity flows, in this subsection we use rolling regressions to investigate the extent to which our parameter estimates change over the sample period. Figures 8 and 9 present graphs of rolling regressions of 12-period ahead equity flows to two representative countries, Mexico and Korea. Each graph shows a coefficient estimate surrounded by its confidence interval. For the first point, the underlying regression is from January 1989 to December 1992. For each subsequent point the starting period is held fixed at January 1989 but the ending point is one month later. For example, a point at March 1995 is from a regression over the period from January 1989 to March 1995. The rolling regressions indicate that our explanatory variables might not properly capture the effects of crises. For example, Mexico's parameter estimates changed substantially around the time of the 1994 Peso crisis. Similarly, there are significant changes during the Asian financial crisis for Korea. ${ }^{19}$ That said, even with the crises-related shifts in parameter estimates, for most variables the story is consistent throughout the sample.

\footnotetext{
18 The cross-listing effect might be greater if the variable was based on the firm's float instead of its market capitalization, but float data are not available back to 1989. Also, abnormal returns prior to a cross-listing (Foerster and Karolyi, 1999; Miller, 1999) suggest that some buying might occur before the actual cross-listing.

${ }^{19}$ Our risk ratings variable, RISK, was included to capture such changes in the investment environment. We tried other variables, including measures of exchange rate variability, to no avail.
} 
The rolling regressions help pinpoint the relationship between Korean capital controls and equity inflows. Recall from Table 5 that Korea is the only country for which a reduction in foreign ownership restrictions (FOR) is associated with reduced long-horizon inflows. As shown in Figure 10, Korea instituted a series of small relaxations of foreign ownership restrictions in the 1990s, starting in 1992 with its initial opening to foreign investment and culminating with a series of incremental reductions of restrictions from late 1994 to early 1997. Over those periods, restrictions were binding and one would expect a relaxation to result in increased capital inflows. This was indeed what occurred; the coefficient estimates suggest that the slight (one percentage point) loosening of restrictions at the end of 1994 resulted in an increase in inflows of about .004 percent of market capitalization per month (or .048 percent overall) over the subsequent 12-month period. But during the Asian financial crisis, Korea greatly relaxed non-binding capital controls and flows did not increase; during the crisis the coefficient estimate of FOR shoots toward zero. Overall, since controls were relaxed in very different environments over the entire sample, the measure of foreign ownership restrictions loses most of its significance by mid-1997.

\section{Summary of Results and Comparison with Past Results}

Table 8 summarizes the evidence from our long- and short-horizon regressions. For each variable, a cell indicates the ratio of significant coefficients to total regressions, as well as the sign. For example, the coefficient on U.S. industrial production, when significant, is negative (indicated by the negative sign in each cell in its row). It is significant more often than any other variable: in all three panel regressions for both long and short horizons, eight of nine long-horizon country-level regressions, and six of nine short-horizon country regressions.

Our two integration variables produced interesting and new results. First, the portfolio rebalancing associated with the cross-listing of an emerging market equity on a U.S. exchange is a very important determinant of short-horizon flows (two of three in the panel and four of seven in country regressions); the effect, however, is not long-lasting because the $C B L$ coefficient, when significant in long-horizon regression, is of a much smaller magnitude. Second, our finding of an important role relationship between capital controls and capital flows is novel. Using annual dummy measures of capital controls, Montiel and Reinhart (1999) found no link between capital controls and the amount of capital inflows. Bekaert et al. (2002) find a post-liberalization increase in inflows of 1.4 percent per year; Edison and Warnock (2003a) fine tune this and show that it is 1.9 percent for a full opening, but only 0.2 percent for a smaller (10 percent) opening. We show here that the effect of changes in capital controls depend on whether they were binding. Analyses of liberalizations are by design studies of the relaxation of binding controls. Our results suggest that relaxations of non-binding controls are not associated with inflows.

A standard result in the literature is that U.S. or global factors play important roles in capital flows to emerging markets (Chuhan et al., 1998; Montiel and Reinhart, 1999; Calvo et al., 1993). Our results point to a greater effect for economic activity than interest rates (which are not significant in the majority of our regressions), so that strong prospective returns on U.S. equities rather than high rates on U.S. fixed income securities seem to be important. This is consistent with the Bekaert et al. (2002) finding of no significant effect for U.S. interest rates, 
but we should add a caveat. In our sample, U.S. interest rates and foreign capital controls are highly correlated (0.51 in Latin America); if FOR is removed from the regressions, US Bond is significant. Thus, we conclude that U.S. factors matter, but we leave for further work the exact role of U.S. interest rates.

On the returns-chasing hypothesis, our results show that investors chase past returns in only a few markets-one of nine in long-horizon regressions and two of nine in the short horizonwhich is not dissimilar to the results of Bohn and Tesar (1996). We found much more evidence of chasing prospective returns as proxied by dividend yields (five of nine in long horizon), consistent with evidence in Bekaert et al. (2002).

\section{Conclusion}

The purpose of this paper is to model portfolio equity flows to emerging markets. We model these flows using two new integration variables that measure the intensity of capital controls and cross-border listings, as well as standard global and country-specific factors. Our results differ from previous work along two important lines. First, we find that the effects of changes in capital controls on capital flows depend importantly on whether controls were binding. Second, we provide the first documentation of the immediate but short-lived effect of cross-border listings on capital flows to emerging markets.

With country-level flows data, we can only speculate that the flows associated with a cross-listing are purchases of the cross-listed firm. Another alternative is that investors become more aware of the emerging market at the time of the cross-listing and reconsider all of its equities. Evidence from Edison and Warnock (2003b), which uses firm-level data on positions (not flows), suggests that the listing effect might be limited to the cross-listed firm and does not extend to other firms in the country. Combined with the results for country-level capital flows in this paper, this suggests that the firm gets funding at the time of the cross-listing and the story ends: The emerging market does not enjoy widespread foreign buying, nor does foreign investment in the cross-listed firm subsequently increase. 
Table 1. Capital Flow Data (billions of U.S. dollars)

\begin{tabular}{|c|c|c|c|c|c|c|c|c|c|c|c|}
\hline & 1989 & 1990 & 1991 & 1992 & 1993 & 1994 & 1995 & 1996 & 1997 & 1998 & 1999 \\
\hline \multicolumn{12}{|l|}{ Latin America and Caribbean } \\
\hline Total flows & 7.1 & 19.4 & 26.9 & 32.7 & 62.8 & 59.2 & 72.1 & 96.2 & 110.9 & 139.3 & 113.6 \\
\hline Portfolio equity flows & 0.4 & 1.1 & 6.3 & 8.3 & 27.2 & 13.2 & 7.6 & 13.9 & 9.9 & 1.7 & 3.9 \\
\hline Foreign direct investment & 8.1 & 8.2 & 12.9 & 15.0 & 13.7 & 28.4 & 29.8 & 43.3 & 65.1 & 72.1 & 90.4 \\
\hline Net flow of long-term debt & -1.5 & 10.1 & 7.7 & 9.4 & 21.9 & 17.6 & 34.7 & 39.0 & 35.9 & 65.5 & 19.3 \\
\hline \multicolumn{12}{|l|}{ Memo $^{1}$} \\
\hline \multicolumn{12}{|l|}{ Latin America share of equity } \\
\hline \multicolumn{12}{|l|}{ East Asia and Pacific } \\
\hline Total flows & 20.7 & 25.6 & 33.3 & 51.7 & 80.8 & 88.9 & 106.2 & 125.1 & 126.8 & 79.9 & 62.6 \\
\hline Portfolio equity flows & 2.6 & 2.3 & 1.2 & 5.3 & 20.7 & 12.6 & 18.3 & 18.1 & 9.2 & 9.0 & 21.1 \\
\hline Foreign direct investment & 9.1 & 11.1 & 14.2 & 22.0 & 39.6 & 46.4 & 53.1 & 61.0 & 65.6 & 63.3 & 56.0 \\
\hline Net flow of long-term debt & 9.0 & 12.2 & 17.9 & 24.4 & 20.5 & 29.9 & 34.8 & 46.0 & 52.0 & 7.6 & -14.5 \\
\hline \multicolumn{12}{|l|}{ Memo $^{1}$} \\
\hline & 0.13 & 0.09 & 0.04 & 0.10 & 0.26 & 0.14 & 0.17 & 0.14 & 0.07 & 0.11 & 0.34 \\
\hline
\end{tabular}

Source: Various issues of Global Development Finance (World Bank).

Note: The regions in this table correspond with World Bank conventions and are much broader than those used in other tables and figures in this paper.

${ }^{1}$ Calculated as Portfolio Equity Flow/Total Flows 
Table 2. Net U.S. Purchases of Emerging Market Stocks (annual averages 1977-1999) in millions of US \$

\begin{tabular}{lcrrr}
\hline & $1977-87$ & $1988-92$ & $1993-97$ & $1998-99$ \\
\hline Argentina & 0 & 8 & 1,085 & $(395)$ \\
Brazil & 1 & 387 & 1,777 & 476 \\
Chile & $(1)$ & 45 & 388 & 147 \\
Mexico & 20 & 1,185 & 1,342 & 318 \\
& & & & \\
Latin America & 20 & 1,624 & 4,592 & 546 \\
memo: world equity flows to Latin America & 19 & 2,950 & 12,060 & 2,461 \\
& & & & \\
Indonesia & $(0)$ & 58 & 528 & $(20)$ \\
Korea & 6 & 89 & 1,659 & 1,936 \\
Malaysia & 9 & 79 & 244 & $(263)$ \\
Philippines & 1 & 60 & 300 & 26 \\
Thailand & 4 & 77 & 36 & 16 \\
Asian emerging markets & 20 & 363 & 2,767 & 1,695 \\
memo: world equity flows to Asian emerging markets & 63 & 1,681 & 10,968 & 12,451 \\
& & & & \\
U.S. Purchases of Foreign Equities & 1,288 & 17,818 & 63,460 & 107,800 \\
of which stock swaps & 0 & 0 & 4,000 & 109,500 \\
$\quad$ with emerging markets & 0 & 0 & 0 & 0 \\
\hline
\end{tabular}

Sources: U.S. Department of Treasury, Treasury International Capital Reporting System; World Bank, Global Development Finance; Securities Data Corporation. 
Table 3. Summary Statistics for Latin American Panel

\begin{tabular}{|c|c|c|c|c|c|c|c|c|c|c|c|c|}
\hline & \multirow[b]{2}{*}{ mean } & \multirow[b]{2}{*}{$\min$} & \multirow[b]{2}{*}{$\max$} & \multirow[b]{2}{*}{ stderr } & \multicolumn{8}{|c|}{ Correlations } \\
\hline & & & & & $\mathrm{Y}_{\mathrm{t}+1} / 1$ & RISK & DY & RET & $\mathrm{CBL}_{\mathrm{t}+1}$ & USIP & USBOND & FOR \\
\hline $\mathrm{Y}_{\mathrm{t}+12} / 12$ & 0.084 & -0.156 & 0.752 & 0.135 & 0.473 & -0.018 & -0.140 & 0.009 & 0.157 & -0.440 & -0.171 & -0.023 \\
\hline $\mathrm{Y}_{\mathrm{t}+1} / 1$ & 0.084 & -1.280 & 2.376 & 0.263 & & 0.035 & -0.080 & 0.092 & 0.386 & -0.238 & -0.108 & -0.025 \\
\hline RISK & 4.215 & 3.784 & 4.425 & 0.115 & & & -0.074 & -0.159 & 0.076 & 0.154 & -0.496 & -0.342 \\
\hline DY & 3.043 & 0.090 & 22.910 & 2.451 & & & & -0.163 & -0.020 & 0.187 & 0.307 & 0.302 \\
\hline RET & 1.103 & -69.004 & 95.841 & 14.011 & & & & & -0.012 & -0.111 & 0.069 & 0.064 \\
\hline $\mathrm{CBL}_{\mathrm{t}+1}$ & 0.003 & 0.000 & 0.208 & 0.017 & & & & & & -0.042 & -0.085 & -0.089 \\
\hline USIP & -1.973 & -9.464 & 11.112 & 5.624 & & & & & & & -0.089 & -0.235 \\
\hline USBOND & 6.238 & 4.170 & 9.610 & 1.318 & & & & & & & & 0.513 \\
\hline FOR & 0.319 & 0.092 & 0.894 & 0.239 & & & & & & & & \\
\hline
\end{tabular}

Variables are defined under equation (3). Summary statistics for the emerging Asian panel are similar and available upon request. 
Table 4a. Panel Data Estimates of 12-Month Ahead Equity Flows

\begin{tabular}{|c|c|c|c|}
\hline Start Date & $\begin{array}{c}\text { Latin America } \\
1989: 1\end{array}$ & $\begin{array}{c}\text { Asia ex. Indonesia } \\
1989: 1\end{array}$ & $\begin{array}{c}\text { Asia } \\
\text { 1990:11 }\end{array}$ \\
\hline \multirow[t]{2}{*}{ RISK } & -0.000 & -0.008 & 0.069 \\
\hline & (0.999) & $(0.844)$ & $(0.131)$ \\
\hline \multirow[t]{2}{*}{ DY } & 0.006 & $0.009 * *$ & 0.007 \\
\hline & $(0.218)$ & $(0.036)$ & $(0.105)$ \\
\hline \multirow[t]{2}{*}{ RET } & $-1.3 \mathrm{E}-4$ & $3.4 \mathrm{E}-5$ & $3.5 \mathrm{E}-6$ \\
\hline & $(0.745)$ & $(0.830)$ & $(0.982)$ \\
\hline \multirow[t]{2}{*}{ FOR } & -0.026 & $-0.067 * * *$ & -0.036 \\
\hline & (0.779) & $(0.002)$ & $(0.101)$ \\
\hline \multirow[t]{2}{*}{$\mathrm{CBL}_{\mathrm{t}+1}$} & $0.875 * *$ & 0.096 & -0.108 \\
\hline & $(0.022)$ & $(0.886)$ & $(0.683)$ \\
\hline \multirow[t]{2}{*}{ USIP } & $-0.012 * * *$ & $-0.002 * * *$ & $-0.003 * * *$ \\
\hline & $(0.000)$ & $(0.007)$ & $(0.000)$ \\
\hline \multirow[t]{2}{*}{ USBOND } & -0.022 & $-0.007 * * *$ & -0.006 \\
\hline & $(0.299)$ & $(0.010)$ & $(0.207)$ \\
\hline $\mathrm{R}^{2}$ & 0.28 & 0.48 & 0.50 \\
\hline
\end{tabular}

Notes: Dependent variable is average 12-period ahead net US purchases of the country's equities normalized by its market capitalization. Samples are through 1999. All independent variables are at time $t$, except CBL, the relative size of a period $t+1$ listing on a US exchange. RISK is the log of the ICRG Composite Risk; RET is the difference in rates of return between the country and the US; DY is the dividend yield; FOR is the intensity of foreign ownership restrictions; USIP is the deviation of US industrial production from a time trend; and USBOND is the rate on a US medium-term bond. Constants are included but not reported. P-values computed using Newey and West (1987) standard errors are in parentheses. ***,**, and * indicate significance at the 1,5 , and 10 percent levels. 
Table 4b. Panel Data Estimates of 12-Month Ahead Equity Flows (with first differences)

\begin{tabular}{|c|c|c|c|}
\hline Start Date & $\begin{array}{c}\text { Latin America } \\
1989: 1\end{array}$ & $\begin{array}{c}\text { Asia ex. Indonesia } \\
1989: 1\end{array}$ & $\begin{array}{c}\text { Asia } \\
\text { 1990:11 }\end{array}$ \\
\hline \multirow[t]{2}{*}{ RISK } & -0.111 & 0.017 & -0.052 \\
\hline & $(0.656)$ & $(0.910)$ & $(0.696)$ \\
\hline \multirow[t]{2}{*}{ DY } & 0.006 & $0.009 * *$ & 0.005 \\
\hline & $(0.208)$ & $(0.029)$ & $(0.218)$ \\
\hline \multirow[t]{2}{*}{ RET } & $-1.4 \mathrm{E}-4$ & $2.8 \mathrm{E}-5$ & $-1.2 \mathrm{E}-4$ \\
\hline & $(0.678)$ & $(0.861)$ & $(0.464)$ \\
\hline \multirow[t]{2}{*}{ FOR } & 0.043 & $-0.064 *$ & $-0.052 * *$ \\
\hline & $(0.662)$ & $(0.067)$ & $(0.014)$ \\
\hline \multirow[t]{2}{*}{$\mathrm{CBL}_{\mathrm{t}+1}$} & $0.877 * *$ & 0.513 & -0.003 \\
\hline & $(0.018)$ & $(0.273)$ & (0.993) \\
\hline \multirow[t]{2}{*}{ USIP } & $-0.012 * * *$ & $-1.4 \mathrm{E}-3$ & $-0.003 * * *$ \\
\hline & $(0.000)$ & $(0.125)$ & $(0.001)$ \\
\hline \multirow[t]{2}{*}{ USBOND } & $-0.024 *$ & $-0.008 * * *$ & -0.006 \\
\hline & $(0.093)$ & $(0.008)$ & $(0.224)$ \\
\hline $\mathrm{R}^{2}$ & 0.28 & 0.42 & 0.48 \\
\hline
\end{tabular}

Notes. Dependent variable is average 12-period ahead net US purchases of the country's equities normalized by its market capitalization. Samples are through 1999. Independent variables are as in Table 4a, except RISK is the log first difference of the ICRG Composite Risk and FOR is the first difference of the intensity of foreign ownership restrictions. Constants are included but not reported. P-values computed using Newey and West (1987) standard errors are in parentheses. $* * *, * *$, and $*$ indicate significance at the 1,5 , and 10 percent levels 
Table 5. Estimation Results, 12-Month Ahead Equity Flows

\begin{tabular}{|c|c|c|c|c|c|c|c|c|c|}
\hline & \multicolumn{4}{|c|}{ Latin America } & \multicolumn{5}{|c|}{ Asia } \\
\hline & Mexico & Argentina & Brazil & Chile & Korea & Indonesia & Malaysia & Philippines & Thailand \\
\hline RISK & $\begin{array}{c}-1.264 * \\
(0.06)\end{array}$ & $\begin{array}{c}-0.458 \\
(0.26)\end{array}$ & $\begin{array}{l}-0.434 * * * \\
(0.00)\end{array}$ & $\begin{array}{c}-0.447 * * * \\
(0.002)\end{array}$ & $\begin{array}{l}0.176 \\
(0.28)\end{array}$ & $\begin{array}{c}0.082 \\
(0.33)\end{array}$ & $\begin{array}{l}0.113 * * * \\
(0.008)\end{array}$ & $\begin{array}{c}-0.008 \\
(0.90)\end{array}$ & $\begin{array}{l}-0.077 * * \\
(0.02)\end{array}$ \\
\hline DY & $\begin{array}{l}0.105 * * * \\
(0.00)\end{array}$ & $\begin{array}{l}0.030 * \\
(0.08)\end{array}$ & $\begin{array}{r}-0.001 \\
(0.41)\end{array}$ & $\begin{array}{l}0.010 * * * \\
(0.00)\end{array}$ & $\begin{array}{l}0.029 * * * \\
(0.002)\end{array}$ & $\begin{array}{c}0.003 \\
(0.58)\end{array}$ & $\begin{array}{l}0.005 \\
(0.90)\end{array}$ & $\begin{array}{c}-0.018 \\
(0.11)\end{array}$ & $\begin{array}{l}0.005^{* * * *} \\
(0.00)\end{array}$ \\
\hline RET & $\begin{array}{l}0.002 * \\
(0.06)\end{array}$ & $\begin{array}{c}-0.001 \\
(0.24)\end{array}$ & $\begin{array}{l}-0.00007 \\
(0.54)\end{array}$ & $\begin{array}{l}0.0003 \\
(0.52)\end{array}$ & $\begin{array}{l}0.0002 \\
(0.40)\end{array}$ & $\begin{array}{l}0.00003 \\
(0.80)\end{array}$ & $\begin{array}{l}0.00006 \\
(0.65)\end{array}$ & $\begin{array}{c}-0.00007 \\
(0.96)\end{array}$ & $\begin{array}{l}-0.00001 \\
(0.21)\end{array}$ \\
\hline FOR & $\begin{array}{c}-0.421 * * \\
(0.03)\end{array}$ & $\begin{array}{c}-2.272 \\
(0.44)\end{array}$ & $\begin{array}{l}-0.282 * * * \\
(0.00)\end{array}$ & $\begin{array}{l}-0.141 * * * \\
(0.01)\end{array}$ & $\begin{array}{l}0.192 * * \\
(0.03)\end{array}$ & $\begin{array}{c}-0.275^{*} \\
(0.09)\end{array}$ & $\begin{array}{c}-0.021 * * * \\
(0.0003)\end{array}$ & $\begin{array}{c}-0.166 \\
(0.15)\end{array}$ & $\begin{array}{c}-0.026 \\
(0.70)\end{array}$ \\
\hline $\mathrm{CBL}_{\mathrm{t}+1}$ & $\begin{array}{r}0.147 \\
(0.58)\end{array}$ & $\begin{array}{l}0.680 * * \\
(0.04)\end{array}$ & $\begin{array}{l}0.193 \\
(0.35)\end{array}$ & $\begin{array}{l}0.565^{* *} \\
(0.02)\end{array}$ & $\begin{array}{l}-1.631 * * * \\
(0.01)\end{array}$ & $\begin{array}{c}-0.027 \\
(0.86)\end{array}$ & n.a. & $\begin{array}{c}-0.263 \\
(0.20)\end{array}$ & n.a. \\
\hline USIP & $\begin{array}{c}-0.018 * * * \\
(0.00)\end{array}$ & $\begin{array}{l}-0.024 * * * \\
(0.00)\end{array}$ & $\begin{array}{l}-0.011 * * * \\
(0.00)\end{array}$ & $\begin{array}{c}-0.003 * \\
(0.07)\end{array}$ & $\begin{array}{l}0.014 * * * \\
(0.00)\end{array}$ & $\begin{array}{l}-0.016 * * * \\
(0.00)\end{array}$ & $\begin{array}{l}-0.003 * * * \\
(0.00)\end{array}$ & $\begin{array}{l}-0.006 * * * \\
(0.00)\end{array}$ & $\begin{array}{r}-0.001 \\
(0.23)\end{array}$ \\
\hline USBOND & $\begin{array}{c}-0.009 \\
(0.57)\end{array}$ & $\begin{array}{c}-0.104 * * * \\
(0.00)\end{array}$ & $\begin{array}{l}0.010 \\
(0217)\end{array}$ & $\begin{array}{c}-0.012 * \\
(0.06)\end{array}$ & $\begin{array}{l}-0.034 * * * \\
(0.00)\end{array}$ & $\begin{array}{c}-0.001 \\
(0.85)\end{array}$ & $\begin{array}{c}-0.004 \\
(0.26)\end{array}$ & $\begin{array}{c}-0.004 \\
(0.33)\end{array}$ & $\begin{array}{c}0.002 \\
(0.47)\end{array}$ \\
\hline $\mathrm{R}^{2}$ & 0.62 & 0.66 & 0.49 & 0.46 & 0.68 & 0.80 & 0.53 & 0.71 & 0.41 \\
\hline
\end{tabular}

Notes: Dependent variable is average 12-period ahead net US purchases of the country's equities scaled by market capitalization. See Table 4 for a description of the independent variables. All regressions are estimated over the period from January 1989 to December 1999, except the regression for Indonesia, which starts in November 1990. P-values computed using Newey and West (1987) standard errors are in parentheses. ***,**, and * indicate significance at the 1, 5, and 10 percent levels. 
Table 6. Panel Data Estimates of One-Month Ahead Equity Flows

\begin{tabular}{lccc}
\hline \multirow{2}{*}{ Start Date } & Latin America & Asia ex. Indonesia & Asia \\
\hline RISK & $1989: 1$ & $1989: 1$ & $1990: 11$ \\
\hline \multirow{2}{*}{ DY } & 0.140 & -0.011 & $0.076^{* *}$ \\
& $(0.303)$ & $(0.789)$ & $(0.014)$ \\
RET & $0.008^{*}$ & 0.006 & 0.0034 \\
& $(0.058)$ & $(0.113)$ & $(0.558)$ \\
FOR & $0.002^{* *}$ & $5.2 \mathrm{E}-4$ & $4.4 \mathrm{E}-4$ \\
& $(0.020)$ & $(0.295)$ & $(0.357)$ \\
CBL & -0.033 & $-0.092^{* * *}$ & $-0.058^{* * *}$ \\
& $(0.601)$ & $(0.000)$ & $(0.006)$ \\
USIP & $5.74 * *$ & 0.522 & $4.66^{* * *}$ \\
& $(0.004)$ & $(0.661)$ & $(0.005)$ \\
USBOND & $-0.012 * * *$ & $-0.002^{* * *}$ & $-0.003^{* * *}$ \\
& $(0.000)$ & $(0.008)$ & $(0.000)$ \\
$\mathrm{R}^{2}$ & -0.017 & $-0.011^{* * *}$ & $-0.015^{* * *}$ \\
\hline
\end{tabular}

Notes. Dependent variable is one-period ahead net U.S. purchases of the country's equities normalized by its market capitalization. Samples are through 1999. See Table 4 for a description of the independent variables. P-values are in parentheses. $*^{* *}, * *$, and $*$ indicate significance at the 1,5 , and 10 percent levels. 
Table 7. Estimation Results, One-Month Ahead Equity Flows

\begin{tabular}{|c|c|c|c|c|c|c|c|c|c|}
\hline & & Latin & erica & & & & Asia & & \\
\hline & Mexico & Argentina & Brazil & Chile & Korea & Indonesia & Malaysia & Philippines & Thailand \\
\hline RISK & 0.496 & 0.232 & $-0.455^{*}$ & -0.234 & $-0.660 * *$ & $0.317 *$ & -0.039 & 0.013 & -0.050 \\
\hline & $(0.55)$ & $(0.59)$ & $(0.09)$ & $(0.17)$ & $(0.02)$ & $(0.10)$ & $(0.70)$ & $(0.91)$ & $(0.53)$ \\
\hline DY & $0.148 * * *$ & 0.033 & -0.006 & $0.011 *$ & -0.001 & $-0.041 *$ & 0.009 & -0.011 & 0.004 \\
\hline & $(0.005)$ & $(0.12)$ & $(0.23)$ & $(0.07)$ & $(0.95)$ & $(0.08)$ & $(0.22)$ & $(0.71)$ & $(0.25)$ \\
\hline RET & $0.006 * *$ & 0.002 & 0.0003 & 0.0006 & 0.0001 & 0.0003 & $0.0009 * *$ & 0.0008 & 0.0002 \\
\hline & $(0.05)$ & $(0.15)$ & $(0.69)$ & $(0.55)$ & $(0.91)$ & $(0.73)$ & $(0.04)$ & $(0.35)$ & $(0.58)$ \\
\hline FOR & $-0.447 *$ & 2.097 & -0.205 & $-0.120 * *$ & $0.540 * * *$ & $-0.591 *$ & $-0.051 * *$ & -0.628 & -0.245 \\
\hline & $(0.10)$ & $(0.57)$ & $(0.31)$ & $(0.03)$ & $(0.00)$ & $(0.06)$ & $(0.02)$ & $(0.13)$ & $(0.88)$ \\
\hline $\mathrm{CBL}_{\mathrm{t}+1}$ & $5.783 * * *$ & $5.948 * * *$ & -0.294 & $4.765 * * *$ & 3.696 & $6.591 * * *$ & n.a. & -1.839 & n.a. \\
\hline & $(0.003)$ & $(0.00)$ & $(0.82)$ & $(0.00)$ & $(0.25)$ & $(0.00)$ & & $(0.28)$ & \\
\hline USIP & $-0.020 * * *$ & $-0.021 * * *$ & $-0.010 * *$ & -0.002 & $0.027 * * *$ & $-0.018 * * *$ & $-0.003 * * *$ & $-0.007 * * *$ & -0.0004 \\
\hline & $(0.0003)$ & $(0.0004)$ & $(0.03)$ & $(0.11)$ & $(0.00)$ & $(0.01)$ & $(0.001)$ & $(0.005)$ & $(0.11)$ \\
\hline USBOND & -0.024 & $-0.083^{* * *}$ & -0.006 & 0.006 & $-0.080 * * *$ & -0.010 & -0.005 & -0.012 & 0.0003 \\
\hline & $(0.42)$ & $(0.01)$ & $(0.76)$ & $(0.53)$ & $(0.00)$ & $(0.53)$ & $(0.18)$ & $(0.22)$ & $(0.55)$ \\
\hline $\mathrm{R}^{2}$ & 0.19 & 0.38 & 0.11 & 0.21 & 0.18 & 0.34 & 0.18 & 0.13 & 0.01 \\
\hline
\end{tabular}

Notes. Dependent variable is one-period ahead net US purchases of the country's equities scaled by market capitalization. See Table 4 for a description of the independent variables. All regressions are estimated over the period from January 1989 to December 1999, except the regression for Indonesia, which starts in November 1990. P-values computed using Newey and West (1987) standard errors are in parentheses. ***,**, and * indicate significance at the 1, 5, and 10 percent levels. 
Table 8. Summary of Results

\begin{tabular}{|c|c|c|c|c|}
\hline & \multicolumn{2}{|c|}{ Long Horizon } & \multicolumn{2}{|c|}{ Short Horizon } \\
\hline & Panel & Countries & Panel & Countries \\
\hline RISK & 0 & $-4 / 9$ & $+1 / 3$ & $-2 / 9$ \\
\hline DY & $+1 / 3$ & $+5 / 9$ & $+1 / 3$ & $+2 / 9$ \\
\hline RET & 0 & $+1 / 9$ & $+1 / 3$ & $+2 / 9$ \\
\hline FOR & $-1 / 3$ & $-5 / 9$ & $-2 / 3$ & $-4 / 9$ \\
\hline $\mathrm{CBL}_{\mathrm{t}+1}$ & $+1 / 3$ & $+2 / 7$ & $+2 / 3$ & $+4 / 7$ \\
\hline USIP & $-3 / 3$ & $-8 / 9$ & $-3 / 3$ & $-6 / 9$ \\
\hline USBOND & $-1 / 3$ & $-3 / 9$ & $-2 / 3$ & $-2 / 9$ \\
\hline
\end{tabular}

Note. The table summarizes significant coefficients from Tables 4, 5, 6, and 7. Listed in each cell is the sign of significant coefficients, followed by the ratio of the number of significant coefficients to the number of regressions. For example, $+1 / 3$ indicates that the variable was positive and significant in one of three panel regressions, while 4/9 indicates negative and significant coefficients in 4 of 9 country-level regressions. If a coefficient was significant and both positive and negative, we report the sign of the most occurrences. 
Figure 1. Monthly Net Purchases of Equities by U.S. Investors (millions of US \$)
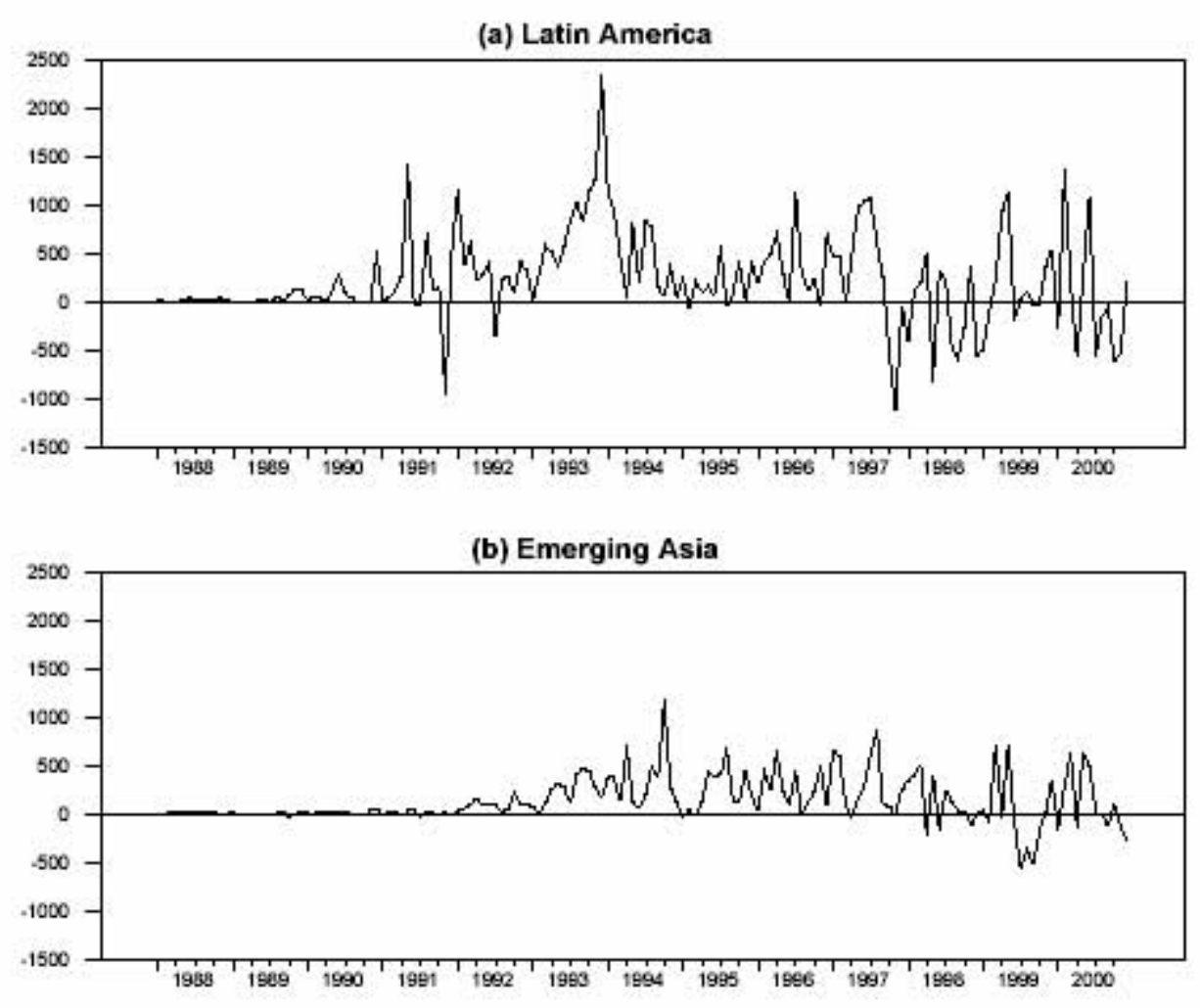
Figure 2. U.S. Positions in Emerging Market Equities (\$ billions)

Estimated (一) Benchmark (x)
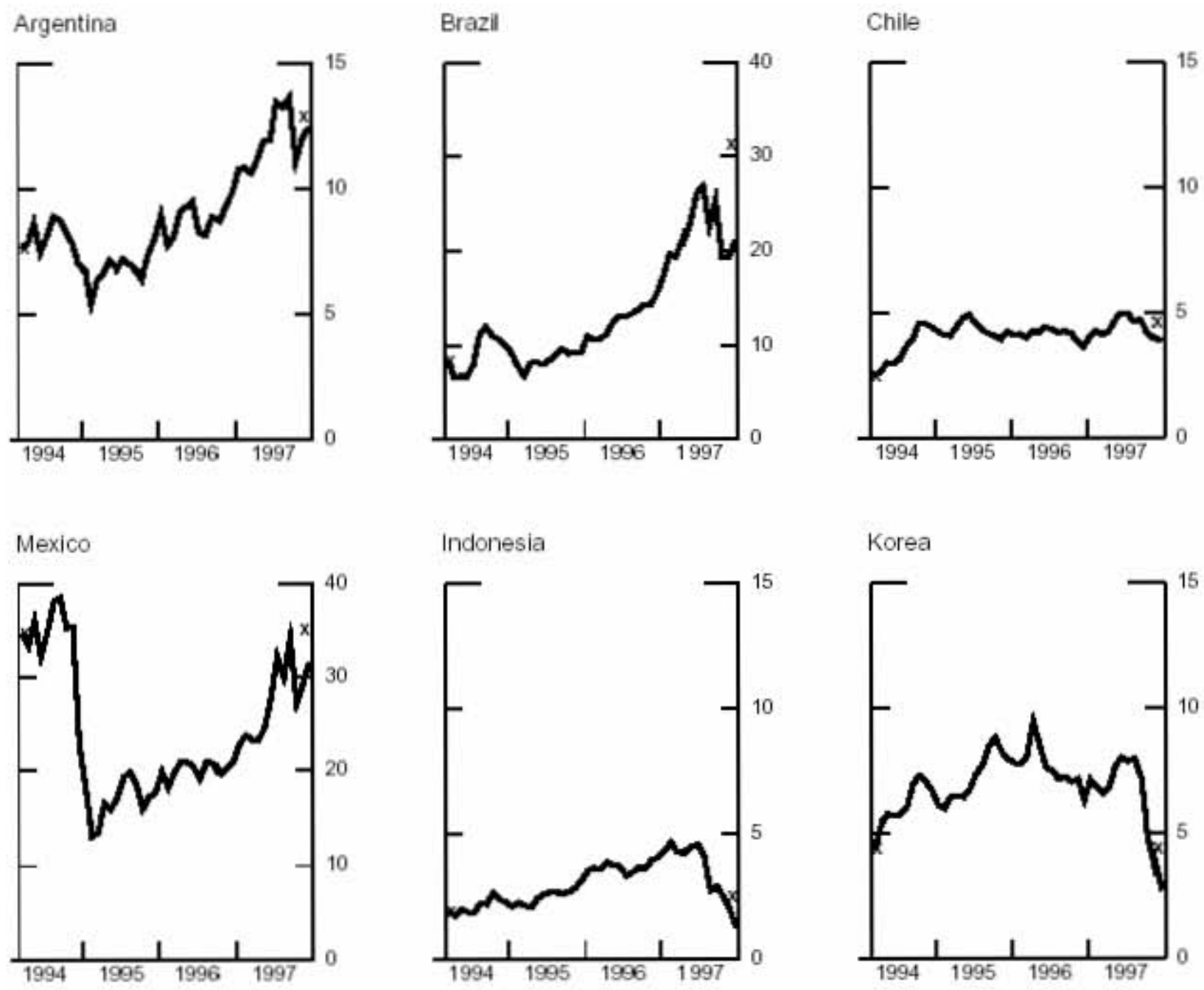

Indonesia

Korea
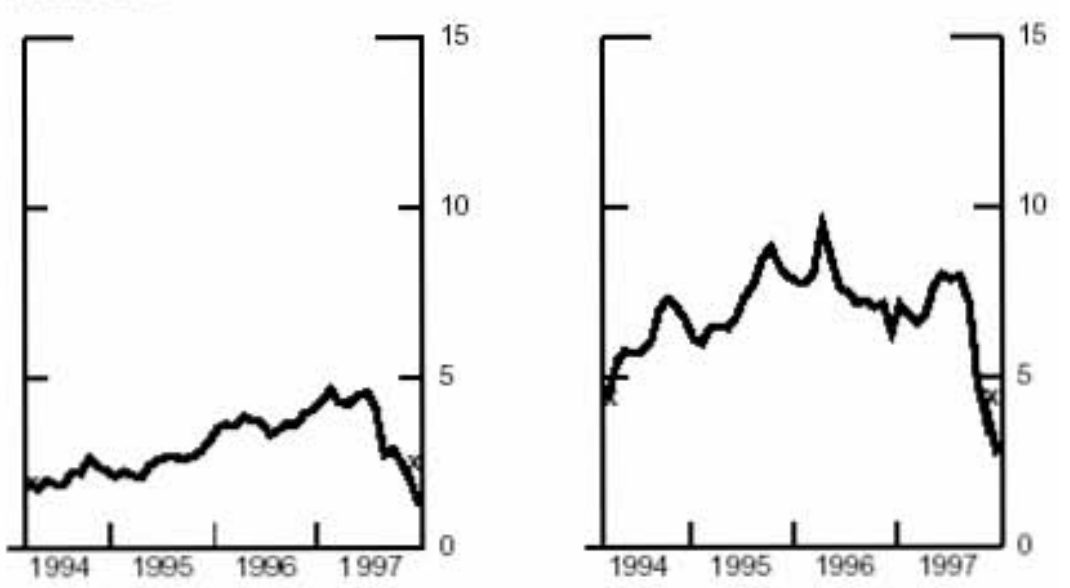

Malaysia

Philippines

Thailand
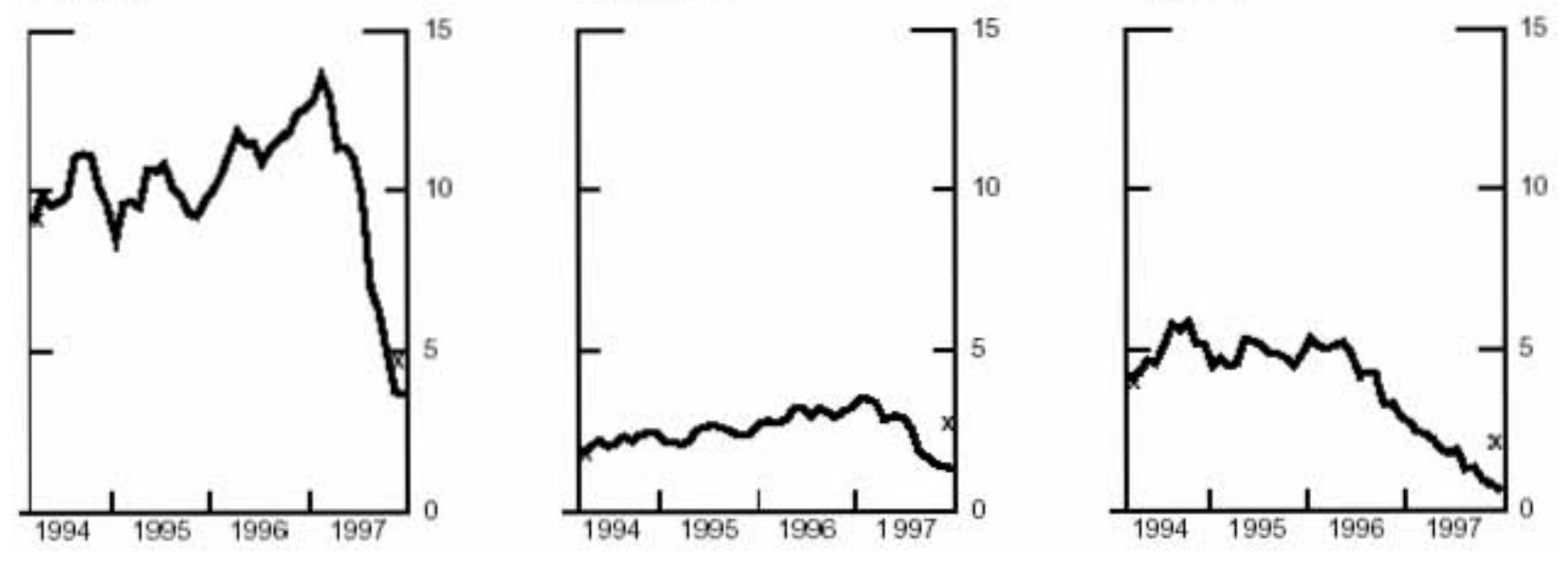
Figure 3. Restrictions on Foreign Ownership of Equities
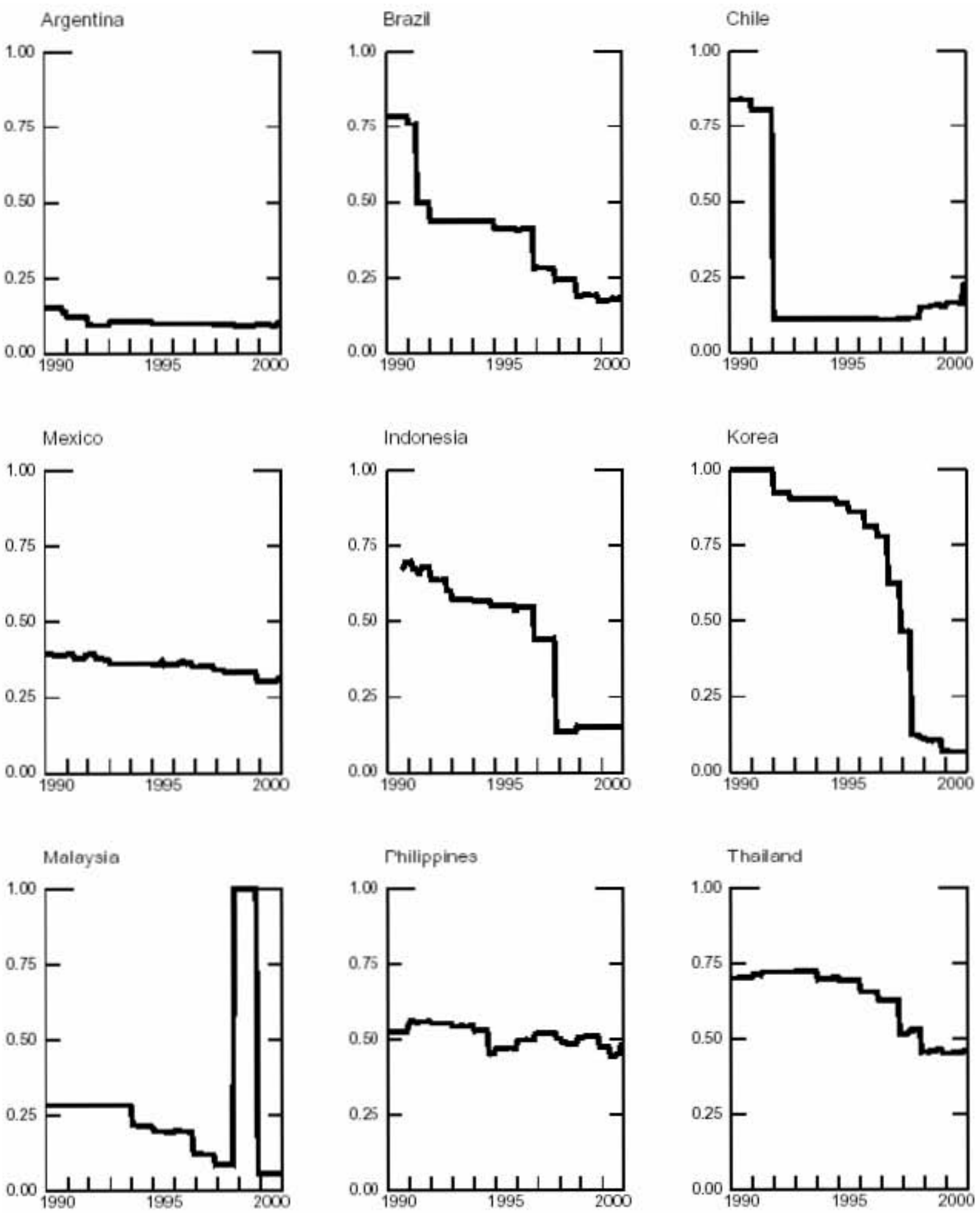

Notes: Foreign ownership restrictions, which range from 0 (no restrictions) to 1 (completely closed to foreign investment), are the smoothed measure from Edison and Warnock (2003a). 
Figure 4. New Listings of Emerging Market Stocks on U.S. Exchanges (percent of local market capitalization)

(a) Latin American Cross-Listings

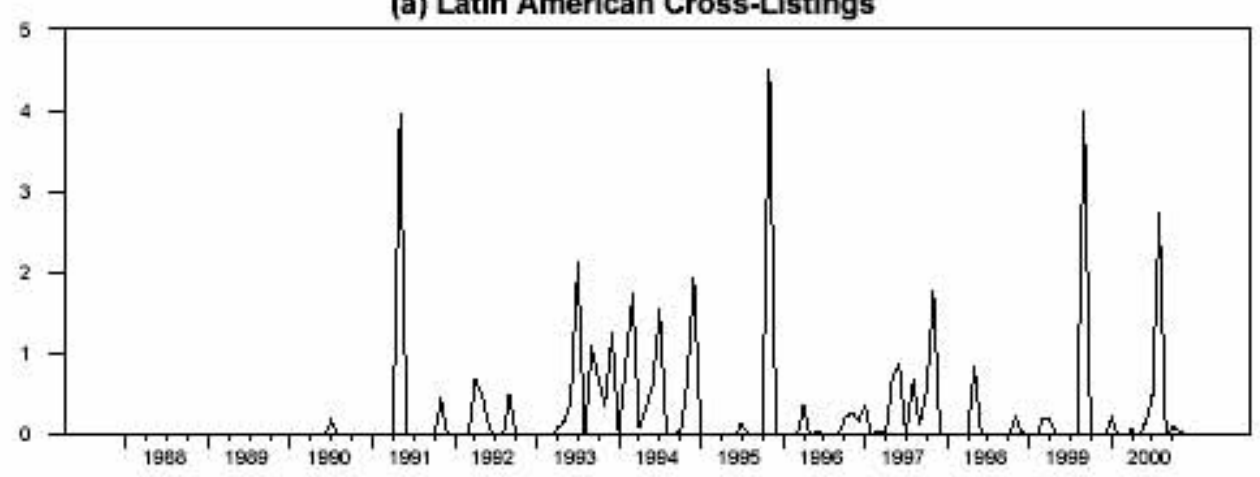

(b) Asian Cross-Listings

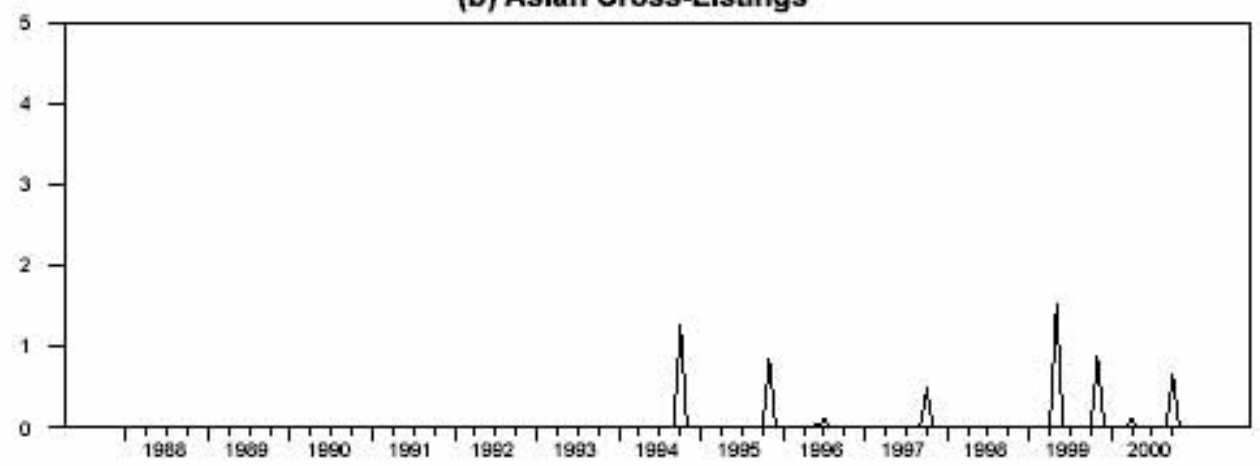


Figure 5. Standard Country-Specific (or "Pull") Factors
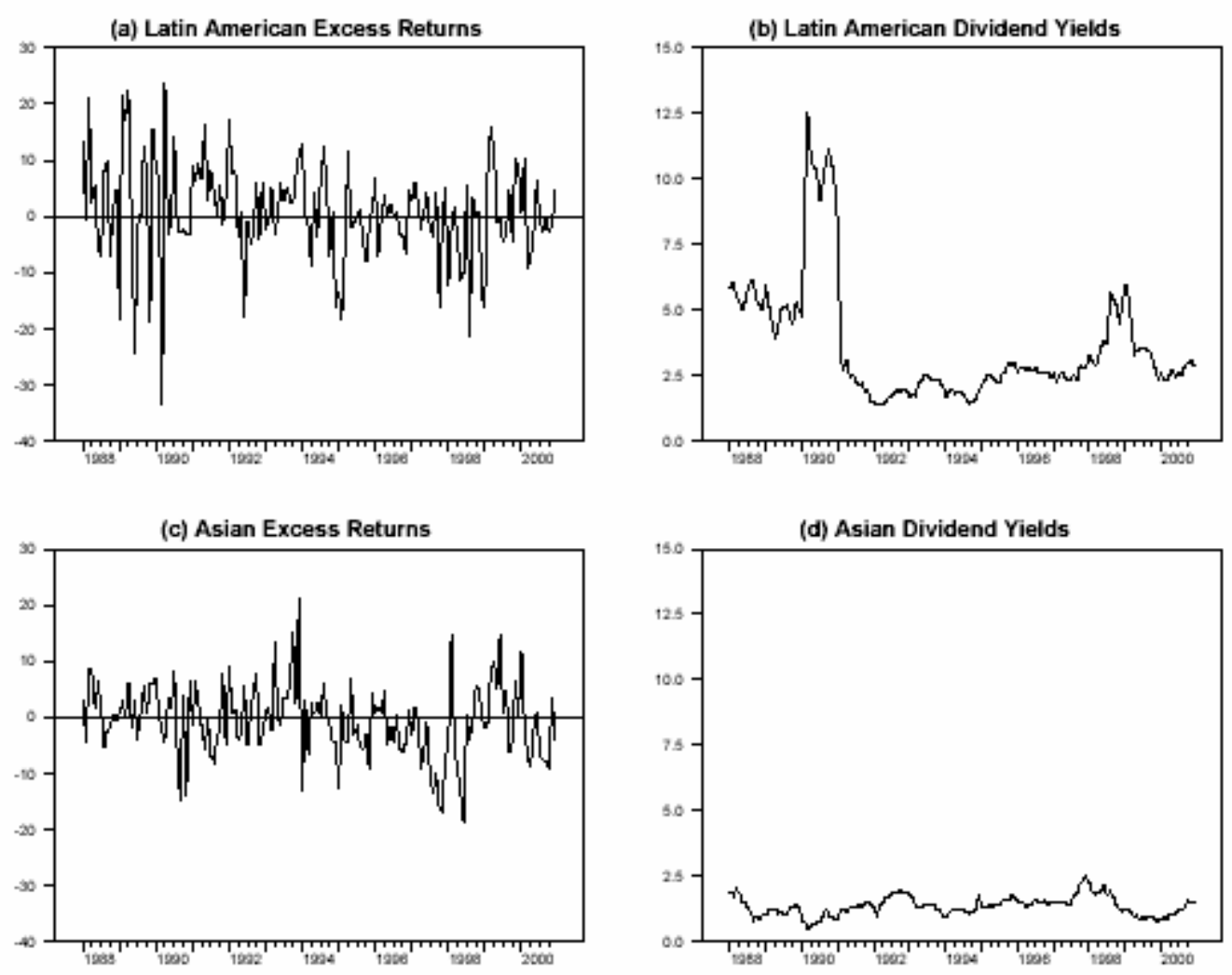

Note: Monthly excess returns are relative to U.S. returns. 
Figure 6. Global (or "Push") Factors

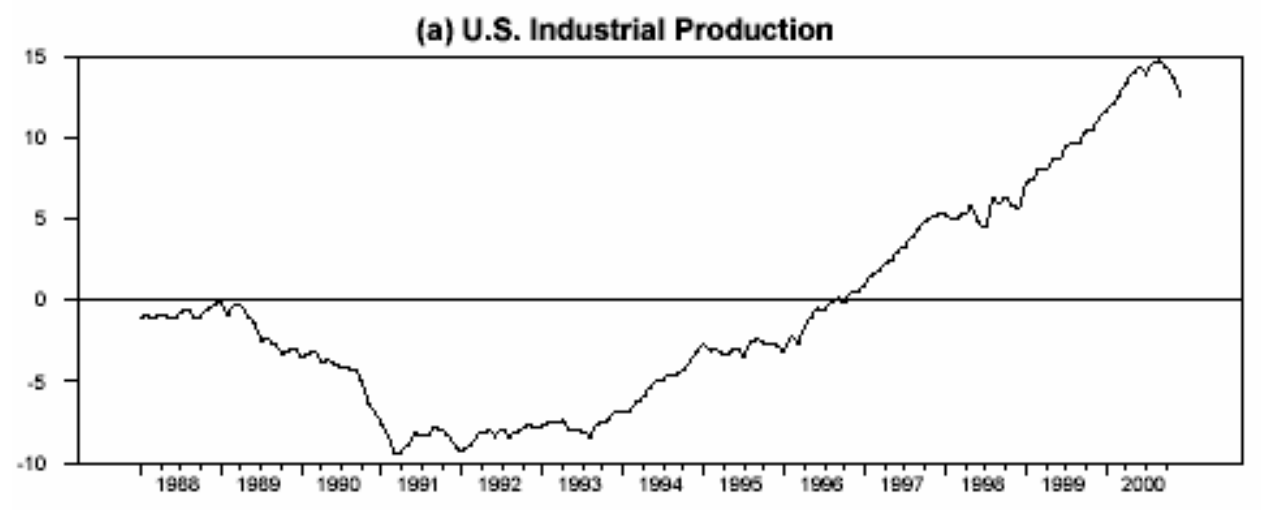

(b) U.S. Bond Rate (\%)

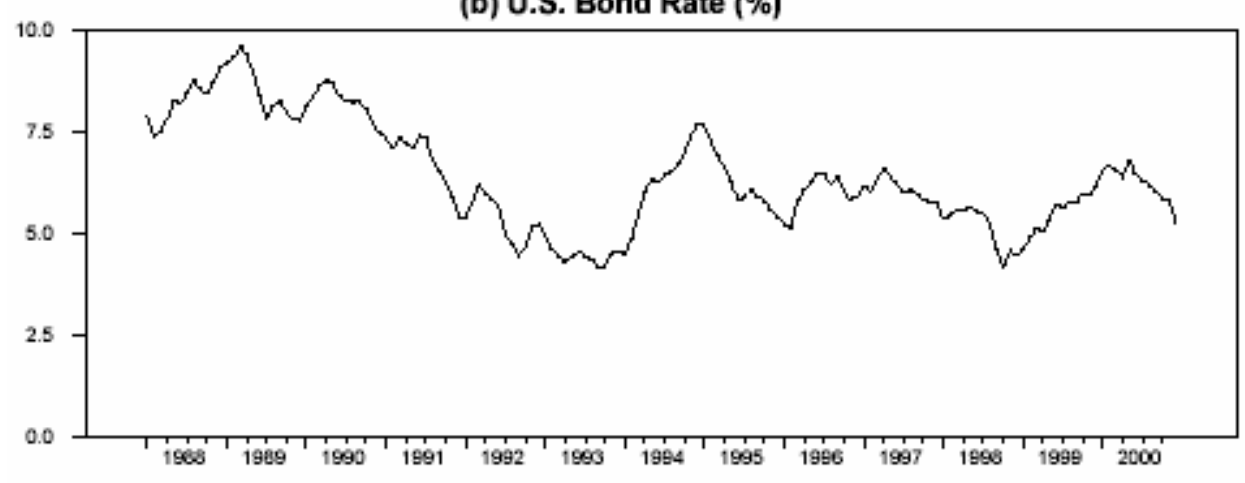

Notes: IP is the deviation from a 1984-2000 time trend. Bond rate (\%) is medium-term. 
Figure 7. Fit of Long-Horizon Regressions, (1989-99)
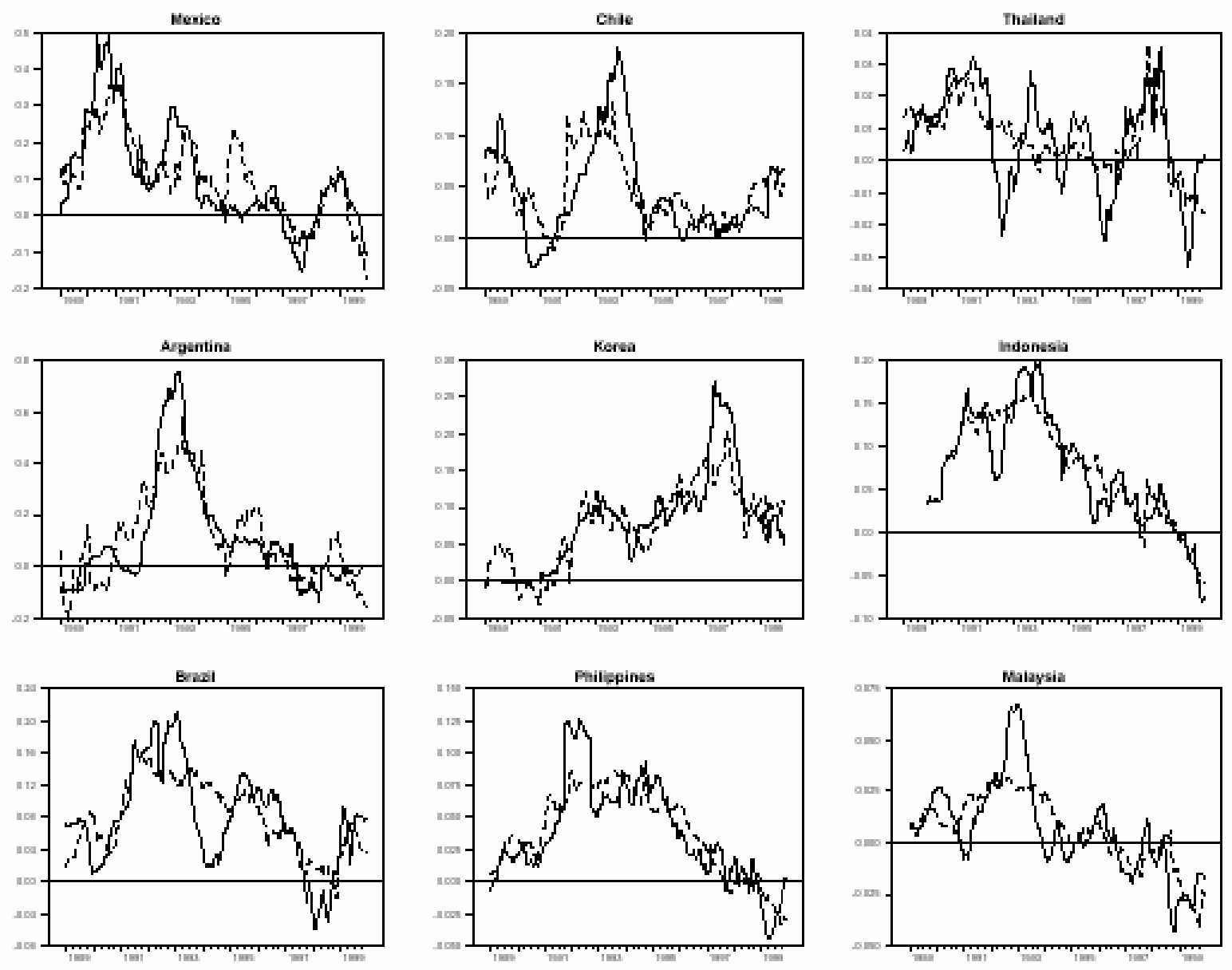

Note: Solid lines show actual 12-month ahead equity flows; dashed lines are fitted values from regressions in Table 5. 
Figure 8. Coefficient Estimates from Rolling Regressions-Mexico
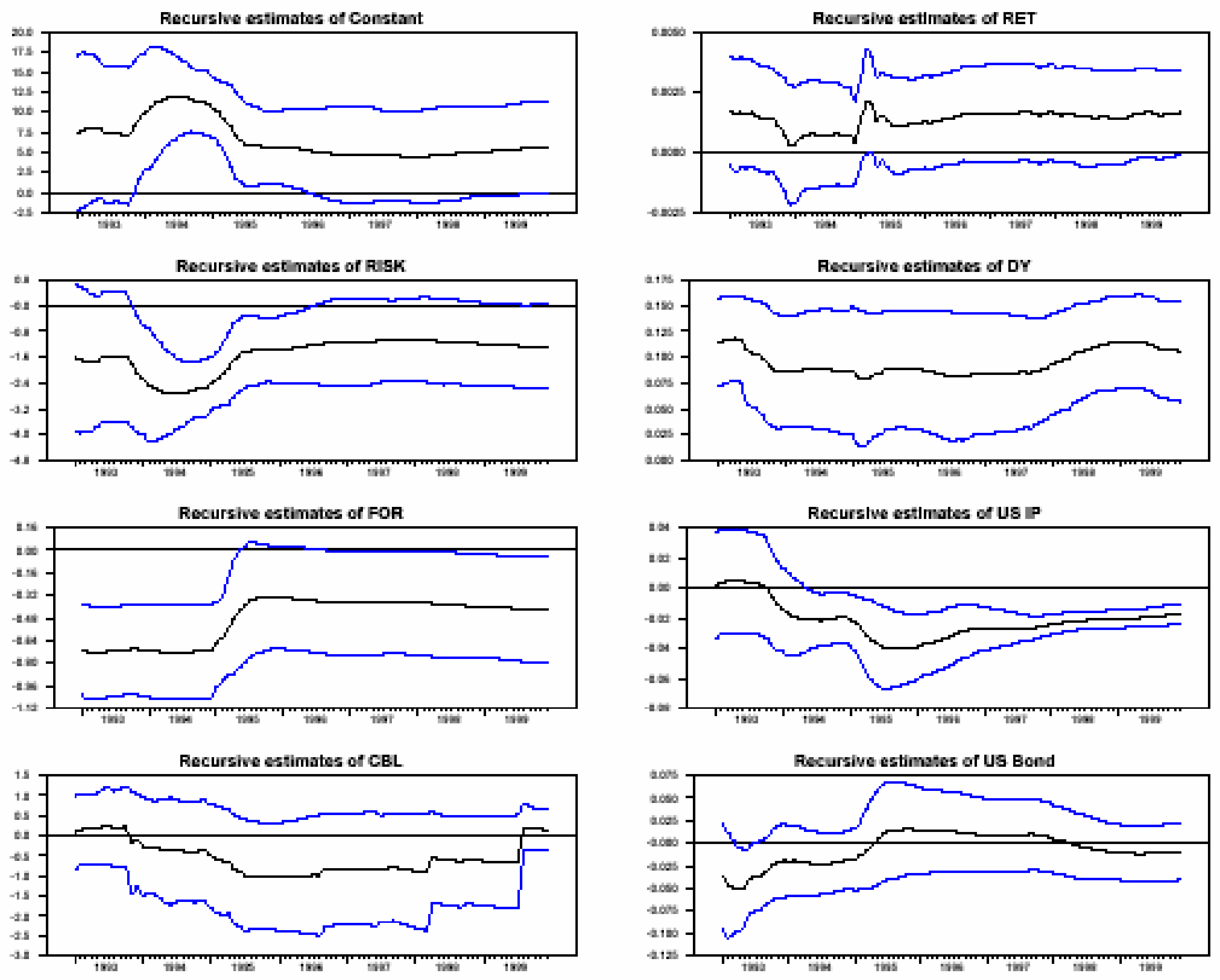

Note: In each panel, the coefficient estimate (middle line) is surrounded by two lines depicting a 10 percent confidence interval. 
Figure 9. Coefficient Estimates from Rolling Regressions-Korea
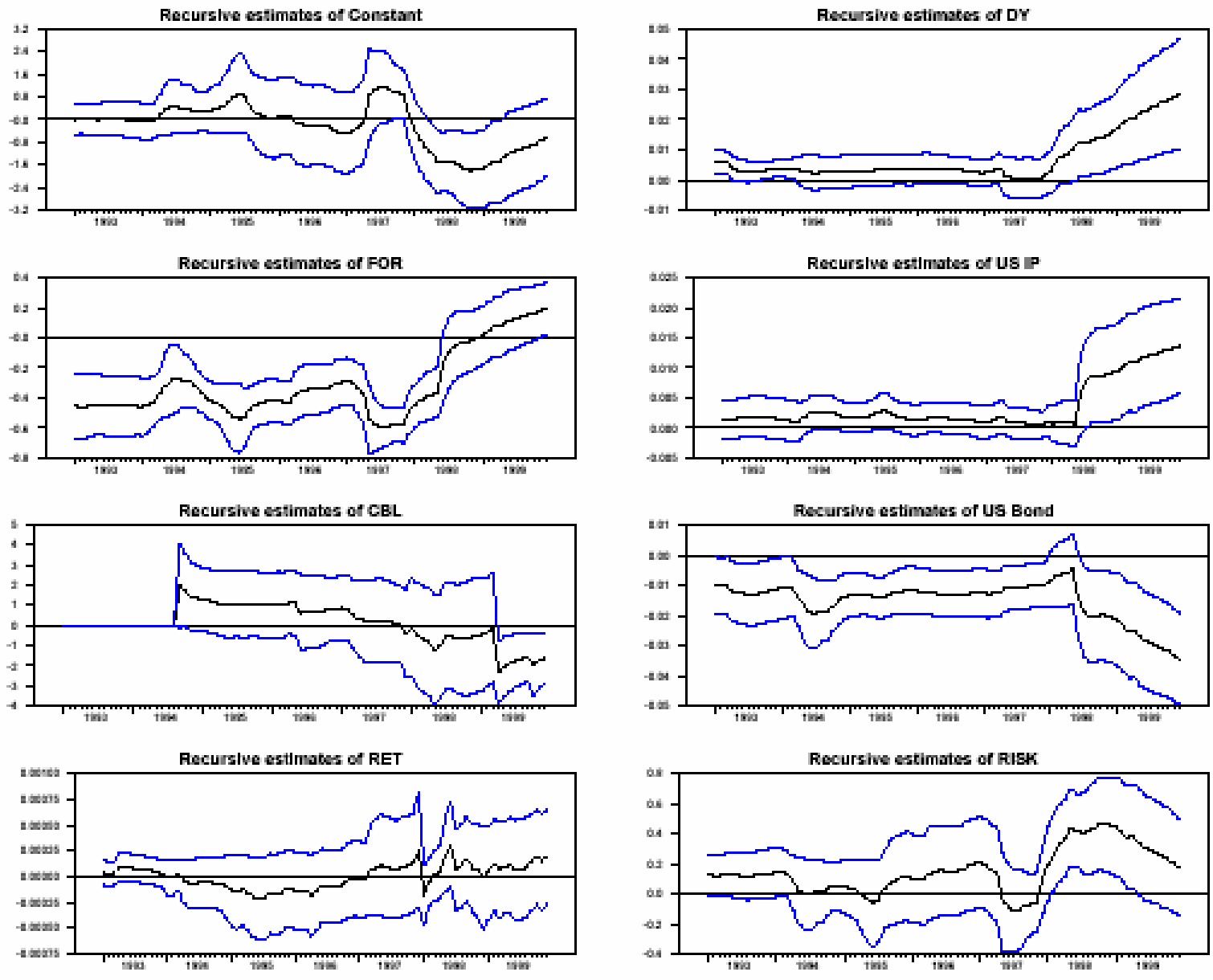

Note: In each panel, the coefficient estimate (middle line) is surrounded by two lines depicting a 10 percent confidence interval. 
Figure 10. Korea-Capital Controls and Equity Inflows
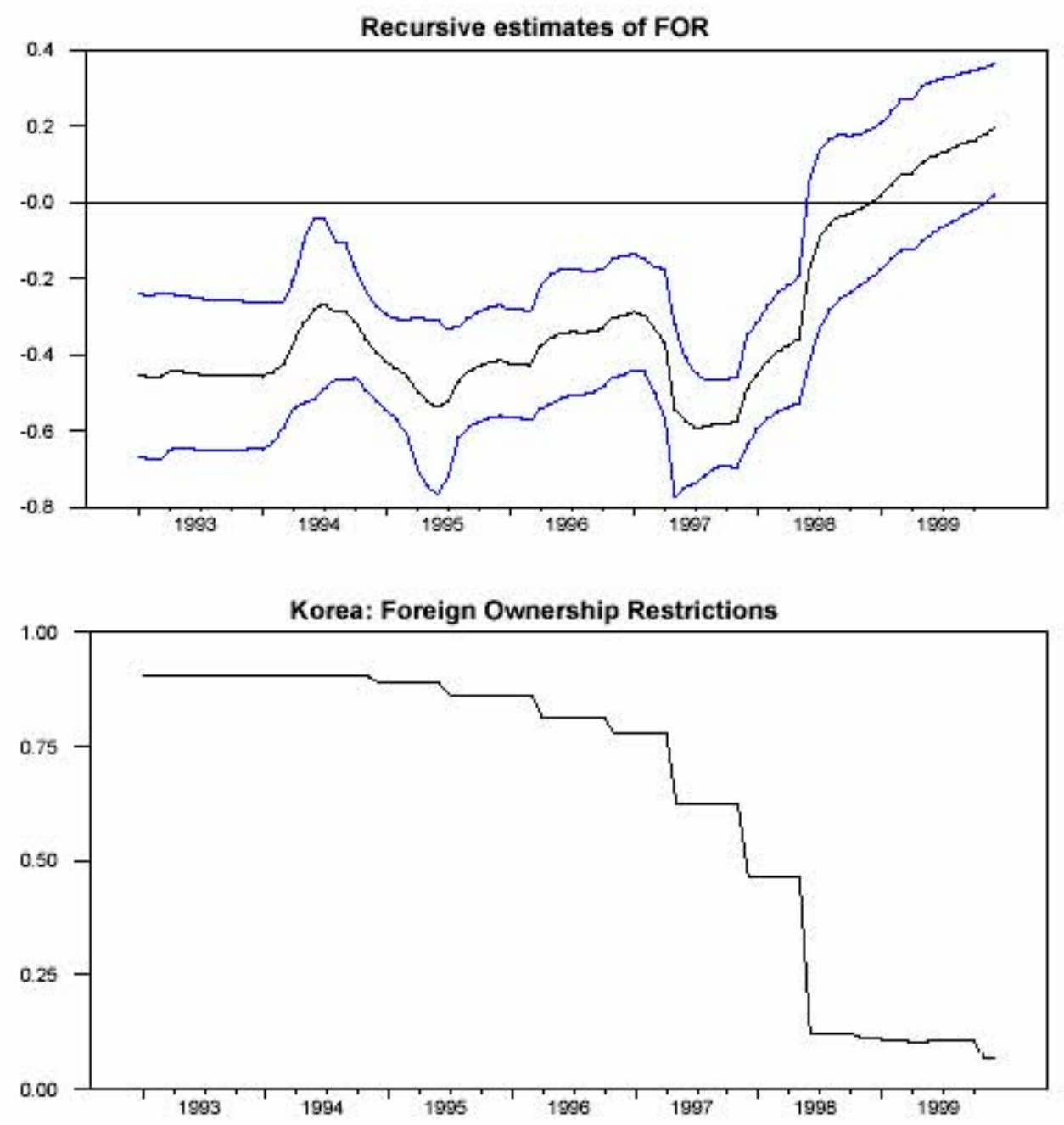


\section{References}

Ahearne, A., W. Griever, and F. Warnock, forthcoming, "Information Costs and Home Bias: An Analysis of U.S. Holdings of Foreign Equities," Journal of International Economics.

Alesina, A., V. Grilli, and G.M. Milesi-Ferretti, 1994, "The Political Economy of Capital Controls, in L. Leiderman and A. Razin, Capital Mobility: The Impact on Consumption, Investment and Growth (Cambridge: Cambridge University Press).

Bacchetta, P., and E. van Wincoop, 2000, "Capital Flows to Emerging Markets: Liberalization, Overshooting, and Volatility" in Capital Flows and the Emerging Economies, ed. by S. Edwards (Chicago: University of Chicago Press).

Bekaert, G., and C.R. Harvey, 1995, “Time-Varying Word Market Integration,” Journal of Finance, Vol. 50, pp. 403-44.

Bekaert G. , C.R. Harvey and R. Lumsdaine, 2002, “The Dynamics of Emerging Market Equity Flows, Journal of International Money and Finance, Vol. 21, pp. 295-350.

Bohn, H., and L. Tesar, 1996, “U.S. Equity Investment in Foreign Markets: Portfolio Rebalancing or Returns Chasing?” American Economic Review, Vol. 86, pp. 77-81.

Brennan, M., and H. Cao, 1997, "International Portfolio Flows," Journal of Finance, Vol. 52, pp. 1851-80.

Calvo, G., L. Leiderman, and C. Reinhart, 1993, "Capital Inflows to Latin America: The Role of External Factors," IMF Staff Papers, Vol. 40, pp. 108-51.

Campbell, J.Y., A.W. Lo, and A.C. McKinlay, 1997, “The Econometrics of Financial Markets” (Princeton, New Jersey: Princeton University Press).

Campbell, J.Y., and R. Shiller, 1988, "Stock Prices, Earnings, and Expected Dividends," Journal of Finance, Vol. 43, pp. 661-76.

Choe, H., B-C Kho, and R. Stulz, 1999, “Do Foreign Investors Destabilize Stock Markets? The Korean Experience in 1997," Journal of Financial Economics, Vol. 54, pp. 227-64.

Chuhan, P., S. Claessens, and N. Mamingi, 1998, "Equity and Bond flows to Latin America and Asia: The Role of Global and Country Factors," Journal of Development Economics, Vol. 55, pp. 439-63. 
Claessens, S., D. Klingebiel, and S. Schmukler, 2002, "The Future of Stock Exchanges in Emerging Economies: Evolution and Prospects," in Brookings-Wharton Papers on Financial Services, ed. by Robert E. Litan and Richard Herring (Washington: Brookings Institution Press).

Doidge, C., A. Karolyi, and R. Stulz, forthcoming, "Why are Foreign Firms Listed in the U.S. Worth More?” Journal of Financial Economics.

Dvorak, T., 2002, "Do Domestic Investors Have an Information Advantage? Evidence from Indonesia," unpublished (Union College).

Edison, H. J., and F. Warnock, 2003a, "A Simple Measure of the Intensity of Capital Controls," Journal of Empirical Finance, Vol. 10, pp. 81-103.

Edison, H. J., and F. Warnock, 2003b. 'U.S. Investors' Emerging Market Equity Portfolios: A Security-Level Analysis," International Finance Discussion Paper No. 771 (Washington: Board of Governors of the Federal Reserve System).

Eichengreen, B., 2001, "Capital Account Liberalizations: What Do Cross-Country Studies Tell Us?" World Bank Economic Review, Vol. 15, pp. 341-65.

Erb, C., C. Harvey, and T. Viskanta, 1996, "Political Risk, Economic Risk, and Financial Risk," Financial Analysts Journal, Vol. 52, pp. 28-46.

Fama, E., and K. French, 1988, “Dividend Yields and Expected Stock Returns,” Journal of Financial Economics, Vol. 22, pp. 3-16.

Foerster, S., and G.A. Karolyi, 1999, "The Effects of Market Segmentation and Investor Recognition on Asset Prices: Evidence from Foreign Stocks Listing in the U.S.," Journal of Finance, Vol. 54.

Froot, K., P.G. O'Connell, and M. Seasholes, 2001, “The Portfolio Flows of International Investors," Journal of Financial Economics, Vol. 59, pp. 151-94.

Griever, W., G. Lee, and F. Warnock, 2001, "The U.S. System for Measuring Cross-Border Investment in Securities: A Primer with a Discussion of Recent Developments," Federal Reserve Bulletin, Vol. 87, pp. 633-50.

Griffin, J., F. Nardari, and R. Stulz, 2002, “Are Daily Cross-Border Flows Pushed or Pulled?" unpublished (Arizona State University and Ohio State University).

Harvey, C., 1995, "Predictable Risk and Returns in Emerging Markets," Review of Financial Studies, Vol. 8, pp. 773-816. 
Karolyi, G.A., 1998, "Why Do Companies List Shares Abroad? A Survey of the Evidence and Its Managerial Implications," Financial Markets, Institutions \& Instruments, Vol. 7.

Karolyi, G.A., 2003, “The Role of ADRs in the Development and Integration of Emerging Equity Markets," unpublished.

Lang, M., Lins, K., and Miller, D., forthcoming, “ADRs, Analysts, and Accuracy: Does Cross Listing in the U.S. Improve a Firm's Information Environment and Increase Market Value?" Journal of Accounting Research.

Levine, R., 2001, "International Financial Liberalization and Economic Growth," Review of International Economics.

Lins, K., D. Strickland, and M. Zenner, 2000, "Do Non-U.S. Firms Issue Equity on U.S. Stock Exchanges to Relax Capital Constraints?" Department of Finance Working Paper No. 2000-5 (Columbus, Ohio: Ohio State University).

Miller, D., 1999, “The Market Reaction to International Cross-Listings: Evidence from Depositary Receipts," Journal of Financial Economics, Vol. 51, pp. 103-23.

Montiel, P., and C. Reinhart, 1999, "Do Capital Controls and Macroeconomic Policies Influence the Volume and Composition of Capital Flows? Evidence from the 1990s," Journal of International Money and Finance, Vol. 18, pp. 619-35.

Newey, W., and K. West, 1987, "A Simple, Positive Semi-Definite, Heteroskedasticity and Autocorrelation Consistent Covariance Matrix," Econometrica, Vol. 55, pp. 703-708.

Pagano, M., A. Roell, and J. Zechner, 2002, "The Geography of Equity Listing: Why Do European Companies List Abroad?” Journal of Finance, Vol. 57, pp. 2651-694.

Pulatkonak, M., and G. Sofianos, 1999, "The Distribution of Global Trading in NYSEListed Non-U.S. Stocks,” NYSE Working Paper No. 99-03.

Quinn, D., 1997, "The Correlates of Changes in International Financial Regulation," American Political Science Review, Vol. 91, pp. 531-51.

Richards, A., 2002, "Big Fish in Small Ponds: The Momentum Investing and Price Impact of Foreign Investors in Asian Emerging Equity Markets," Working Paper, Reserve Bank of Australia and IMF.

Rodrik, D., 1998, "Who Needs Capital-Account Convertibility?" in Should the IMF Pursue Capital-Account Convertibility?, ed. by Stanley Fischer et al. (Princeton, N.J.: International Finance Section Department of Economics, Princeton University). 
Seasholes, M., 2000, “Smart Foreign Traders in Emerging Markets," unpublished (University of California, Berkeley).

Taylor, M., and L. Sarno, 1997, "Capital Flows to Developing Countries: Long- and Short-Term Determinants," World Bank Economic Review, Vol. 11, pp. 451-70.

Tesar, L., and I. Werner, 1994, "International Equity Transactions and U.S. Portfolio Choice," in The Internationalization of Equity Markets, ed. by J. Frankel (Chicago: University of Chicago Press).

Tribukait, H., 2003, “The Invisible Enforcer? Price Behavior of Mexican Firms Cross-Listed on the NYSE Around Earnings Announcements," unpublished (Harvard University).

Warnock, F., and C. Cleaver, 2003, "Financial Centers and the Geography of Capital Flows," International Finance, Vol. 6, pp. 27-59. 


\section{Description of Data and Sources}

Equity flows from the U.S. to emerging markets are from the Treasury International Capital Reporting System (TIC), available at http://www.treas.gov/tic/.

Our CBL variable is formed using data on the worldwide market capitalization of foreign firms listed on U.S. exchanges, taken mainly from the NYSE, whose data match well with the Bank of New York's ADR Index (available only from September 1998 onward). NYSE data are for year-end 1990, 1993, and 1996-1999. For firms listed in intermediate years, CompuStat data were used when they matched well with overlapping NYSE data. For the firms where CompuStat data did not match overlapping NYSE data, the first available NYSE data point and changes in CompuStat market capitalization figures were used to form an estimate. Country-level market capitalization data are from IFC/S\&P Emerging Stock Markets Factbooks, various years.

Our measure of foreign ownership restrictions uses monthly price and market capitalization data for the IFC/S\&P Investable and Global Indexes. See Edison and Warnock (2003a) for a complete discussion.

Equity returns are from Morgan Stanley MSCI indexes (www.mscidata.com).

Dividend yields, from the IFC, are a 12-month moving average of dividends divided by the current price level.

The risk measure is the International Country Risk Guide's (ICRG) Composite Index; see Erb, Harvey, and Viskanta (1996).

U.S. industrial production and the U.S. interest rate on a medium-term U.S. bond are from the IMF's IFS data set.

Countries included in panel regressions are the same as in single-country regressions and include Argentina, Brazil, Chile, and Mexico (for Latin America) and Indonesia, Korea, Malaysia, Philippines, and Thailand (for emerging Asia). 
Appendix B

$$
-41-
$$

\section{Listings on U.S. Stock Exchanges}

\begin{tabular}{|c|c|c|c|c|}
\hline Country & Symbol & Company & Date Listed & Size \\
\hline \multirow{16}{*}{ Argentina } & BAE & BAESA & $5 / 5 / 93$ & $2.3 \%$ \\
\hline & YPF & YPF & $6 / 29 / 93$ & $20.8 \%$ \\
\hline & BFR & Banco Frances del Rio & $11 / 24 / 93$ & $3.2 \%$ \\
\hline & TAR & TELEFONICA DE ARGENTINA & $3 / 8 / 94$ & $16.9 \%$ \\
\hline & MGS & METROGAS SA & $11 / 17 / 94$ & $1.4 \%$ \\
\hline & TGS & TRANSPORT GAS SUR & $11 / 17 / 94$ & $4.0 \%$ \\
\hline & TEO & TELECOM ARGENTINA STET FRANC & $12 / 9 / 94$ & $13.8 \%$ \\
\hline & IRS & IRSA INVESIONES Y & $12 / 20 / 94$ & $0.8 \%$ \\
\hline & LQU & QUILMES INDL QUINSA -ADR & $3 / 28 / 96$ & $2.4 \%$ \\
\hline & DXO & DISCO SA & $4 / 3 / 96$ & $1.0 \%$ \\
\hline & CRESY & Cresud S.A.C.I.F.y A. (NASDAQ) & $3 / 19 / 97$ & $0.5 \%$ \\
\hline & NTL & Nortel Inversora S.A. & $6 / 17 / 97$ & $1.1 \%$ \\
\hline & BRS & Banco Rio de la Plata S.A. (Banco Rio) & $10 / 10 / 97$ & $3.1 \%$ \\
\hline & $\mathrm{PC}$ & Perez Companc & $1 / 26 / 00$ & $1.4 \%$ \\
\hline & GGAL & Grupo Financiero Galicia S.A. (NASDAQ) & $6 / 22 / 00$ & $0.7 \%$ \\
\hline & APSA & Alto Pamero (NASDAQ) & $11 / 10 / 00$ & $0.2 \%$ \\
\hline \multirow[t]{16}{*}{ Brazil } & ARA & Aracruz Celulose & $5 / 27 / 92$ & $2.1 \%$ \\
\hline & TBR & TELEC BRASILEIRAS- & $11 / 1 / 95$ & $9.9 \%$ \\
\hline & GLCBY & Globo Cabo S.A. (NASDAQ) & $11 / 1 / 96$ & $0.6 \%$ \\
\hline & UBB & União de Bancos Brasileiros S.A. (Unibanco) & $5 / 22 / 97$ & $1.3 \%$ \\
\hline & CBD & Companhia Brasileira de Distribuição & $5 / 29 / 97$ & $0.2 \%$ \\
\hline & $\mathrm{BRH}$ & Companhia Cervejaria Brahma & 6/4/97 & $1.2 \%$ \\
\hline & ELP & Companhia Paranaense de Energia-COPEL & 7/30/97 & $1.1 \%$ \\
\hline & SID & Companhia Siderurgica Nacional (CSN) & $11 / 14 / 97$ & $7.0 \%$ \\
\hline & PNE & Copene-Petroquimica do Nordeste $\mathrm{S}$. & $12 / 21 / 98$ & $0.1 \%$ \\
\hline & GGB & Gerdau & 3/10/99 & $0.5 \%$ \\
\hline & UGP & Ultra Participacoes SA & $10 / 7 / 99$ & $0.0 \%$ \\
\hline & VCP & Votorantim Celulose E Papel & $4 / 14 / 00$ & $0.2 \%$ \\
\hline & PBR & Petroleo Brasiliero S.A. & $8 / 10 / 00$ & $7.1 \%$ \\
\hline & PDA & Perdigao S.A. & $10 / 20 / 00$ & $0.1 \%$ \\
\hline & ERJ & Embraer & $7 / 21 / 00$ & $1.3 \%$ \\
\hline & RIO & Companhia Vale Do Rio Doce (CVRD) & $6 / 20 / 00$ & \\
\hline \multirow[t]{22}{*}{ Chile } & CTC & Cia. De Telefonos de Chile & $7 / 20 / 90$ & $5.4 \%$ \\
\hline & $\mathrm{CU}$ & Comp. Cervecerias Unidas SA (NASDAQ) & $9 / 25 / 92$ & $3.4 \%$ \\
\hline & MAD & Madeco & $5 / 28 / 93$ & $2.1 \%$ \\
\hline & MYS & MASISA & $6 / 17 / 93$ & $1.3 \%$ \\
\hline & SQM & SQM-Soc Quim.y Minera & 9/21/93 & $1.5 \%$ \\
\hline & ENI & Enersis & $10 / 20 / 93$ & $6.2 \%$ \\
\hline & CGW & CRISTALERIA CHILE & $1 / 25 / 94$ & $0.5 \%$ \\
\hline & LBC & LABORATORIO CHILE & $6 / 29 / 94$ & $0.5 \%$ \\
\hline & AKOA & EMBOTELLA ANDINA & $7 / 6 / 94$ & $2.2 \%$ \\
\hline & CHR & Gener S.A. (formerly chilignener) & $7 / 19 / 94$ & $2.2 \%$ \\
\hline & EOC & EMP NAC ELECTRICID & $7 / 24 / 94$ & $10.2 \%$ \\
\hline & BSB & Banco Santander-Chile & $11 / 4 / 94$ & $1.8 \%$ \\
\hline & TL & Empresas Telex Chile S.A. & $10 / 14 / 94$ & $0.9 \%$ \\
\hline & $\mathrm{VCO}$ & VINA CONCHA Y TORO & $10 / 14 / 94$ & $0.3 \%$ \\
\hline & PVD & ADMIN FONDOS PENSIONS - ADR & $11 / 16 / 94$ & $0.4 \%$ \\
\hline & ISA & SANTA ISABEL SA & $7 / 25 / 95$ & $0.7 \%$ \\
\hline & AED & BCO DE A EDWARDS & $11 / 3 / 95$ & $0.9 \%$ \\
\hline & $\mathrm{BB}$ & BANCO BHIF & $6 / 19 / 96$ & $0.3 \%$ \\
\hline & SAN & Banco Santiago & $1 / 13 / 97$ & $2.5 \%$ \\
\hline & UNR & Supermercados Unimarc S.A. & $5 / 9 / 97$ & $0.4 \%$ \\
\hline & LQ & QUIÑENCO S.A.* & $6 / 25 / 97$ & $1.3 \%$ \\
\hline & DYS & Distribución y Servicio D\&S S.A. (D\&S) & $10 / 8 / 97$ & $1.8 \%$ \\
\hline
\end{tabular}




\begin{tabular}{|c|c|c|c|c|}
\hline & $\begin{array}{l}\text { LFL } \\
\text { SQMA }\end{array}$ & $\begin{array}{l}\text { Lan Chile S.A. } \\
\text { SQM-Sociedad Química y Minera de Chile, S.A.* }\end{array}$ & $\begin{array}{r}11 / 7 / 97 \\
4 / 8 / 99\end{array}$ & $\begin{array}{l}1.1 \% \\
1.3 \%\end{array}$ \\
\hline \multirow{32}{*}{ Mexico } & TMX & Telefonos de Mex. & $5 / 14 / 91$ & $8.1 \%$ \\
\hline & VTO & Vitro & $11 / 19 / 91$ & $0.8 \%$ \\
\hline & ICA & Empresas ICA & 4/9/92 & $1.4 \%$ \\
\hline & TMM & Transportacion Maritima Mexicana & $6 / 10 / 92$ & $0.2 \%$ \\
\hline & DIN & Consorcio G Gpo Dina & $3 / 31 / 93$ & $0.2 \%$ \\
\hline & $\mathrm{RC}$ & Gpo. Radio Centro & 7/1/93 & $0.2 \%$ \\
\hline & KOF & Coca-Cola Femsa & 9/14/93 & $0.8 \%$ \\
\hline & GTR & Gpo. Tribasa & 9/22/93 & $1.2 \%$ \\
\hline & GBI & Bufete Industrial & $11 / 4 / 93$ & $0.1 \%$ \\
\hline & SFN & Gpo. Financiero Serfin & $12 / 1 / 93$ & $0.5 \%$ \\
\hline & ATY & Grupo Casa Autrey & $12 / 7 / 93$ & $0.1 \%$ \\
\hline & GMD & Gpo. Mex de Desarrollo & $12 / 14 / 93$ & $0.2 \%$ \\
\hline & $\mathrm{TV}$ & Gpo. Televisa & $12 / 14 / 93$ & $1.7 \%$ \\
\hline & ELM & EMPRESAS LA MODERN & $2 / 2 / 94$ & $1.9 \%$ \\
\hline & GEM & Pepsi-Gemex & $3 / 29 / 94$ & $0.2 \%$ \\
\hline & MSK & GPO IND MASECA & $5 / 17 / 94$ & $0.8 \%$ \\
\hline & CEL & GRUPO IUSACELL & $6 / 15 / 94$ & $1.4 \%$ \\
\hline & SDK & GRUPO SIDEK (removed 3/21/97) & $7 / 12 / 94$ & $0.8 \%$ \\
\hline & DES & DESC SA DE CV & $7 / 14 / 94$ & $1.2 \%$ \\
\hline & GID & GPO IND DURANGO & $7 / 15 / 94$ & $0.3 \%$ \\
\hline & EKT & GPO ELEKTRA & $12 / 5 / 94$ & $1.9 \%$ \\
\hline & ICM & INTL DE CERAMICA & $12 / 8 / 94$ & $0.3 \%$ \\
\hline & MCM & CONTROL COM MEX10/11/960.9\% & & \\
\hline & IAM & ALTOS HORNOS MEXIC & $12 / 11 / 96$ & $0.8 \%$ \\
\hline & IMY & GRUPO IMSA SA DE CV - ADS & $12 / 11 / 96$ & $0.6 \%$ \\
\hline & TZA & TV Azteca, S.A. & $8 / 15 / 97$ & $2.0 \%$ \\
\hline & IBA & Industrias Bachoco, S.A. de C.V. (Bachoco) & 9/19/97 & $0.6 \%$ \\
\hline & FMX & Fomento Económico Mexicano, S.A. de C.V.* (FEMSA) & $5 / 11 / 98$ & $3.2 \%$ \\
\hline & BIPRY & BIPER SA (NASDAQ) & 9/28/98 & $0.1 \%$ \\
\hline & GMK & Gruma S.A. de C.V.* & $11 / 6 / 98$ & $1.0 \%$ \\
\hline & $\mathrm{CX}$ & Cemex & 9/15/99 & $13.1 \%$ \\
\hline & ASR & Grupo Aeroportuario del Sureste & $10 / 3 / 00$ & $0.3 \%$ \\
\hline \multirow[t]{5}{*}{ Indonesia } & IIT & INDOSAT & $10 / 18 / 94$ & $7.8 \%$ \\
\hline & TLK & TELEKOMUNIKASI IND & $11 / 14 / 95$ & $17.7 \%$ \\
\hline & TPI & PT TRI POLYTA INDONSIA - ADR & $3 / 14 / 96$ & $0.2 \%$ \\
\hline & PSNRE & P.T. Pasifik Satelit Nusantara (NASDAQ) & $6 / 11 / 96$ & $0.4 \%$ \\
\hline & GRL & Gulf Indonesia Resources Limited & $9 / 30 / 97$ & $5.4 \%$ \\
\hline \multirow[t]{8}{*}{ Korea } & PKX & POHANG IRON\&STEEL & $10 / 14 / 94$ & $3.3 \%$ \\
\hline & KEP & KOREA ELEC POWER & $10 / 27 / 94$ & $10.7 \%$ \\
\hline & SKM & SK Telecom Co. Ltd. (formerly Korea Mobile Telec) & $6 / 27 / 96$ & $2.2 \%$ \\
\hline & KTC & Korea Telcom Corp. & $5 / 26 / 99$ & $11.0 \%$ \\
\hline & KOREA & Korea Thrunet Co. Ltd (NASDAQ) & $11 / 1 / 99$ & $1.5 \%$ \\
\hline & MRAE & Mirae Corporation (NASDAQ) & $11 / 1 / 99$ & $0.3 \%$ \\
\hline & HANA & Hanaro Telecom Inc. (NASDAQ) & $3 / 30 / 00$ & $0.3 \%$ \\
\hline & $\mathrm{HCB}$ & $\mathrm{H} \& \mathrm{CB}$ & $9 / 29 / 00$ & $1.4 \%$ \\
\hline \multirow[t]{3}{*}{ Philippines } & PHI & PHILIPPINE LNG DIS & $10 / 19 / 94$ & $5.3 \%$ \\
\hline & PHIPRA & Philippine Long Distance Telephone Company*** (PFD) & $11 / 22 / 94$ & \\
\hline & PSIT & PSI Technologies Holdings, Inc. (NASDAQ) & $3 / 21 / 00$ & $0.1 \%$ \\
\hline
\end{tabular}

Notes: All listings are on the NYSE unless otherwise noted. Size refers to firm's size relative to the country's market capitalizaiton, calculated by the authors using year-end values. Settlement conventions are such that listings on the last three to five trading days of a month appear in the following month's capital flow data. No firms from Malaysia or Thailand listed on a U.S. exchange between 1988 and 1999. 